TESSA MCKEOWN

\title{
HATE SPEECH AND HOLOCAUST DENIAL: THE PROHIBITION OF FALSE HISTORICAL DISCOURSE IN MODERN SOCIETY
}

\author{
LLM RESEARCH PAPER \\ LAWS 520: CENSORSHIP AND THE FREEDOM OF EXPRESSION
}

FACULTY OF LAW

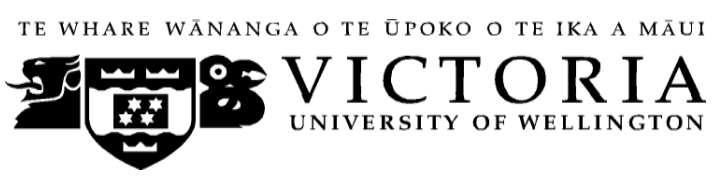

2014 


\section{Contents}

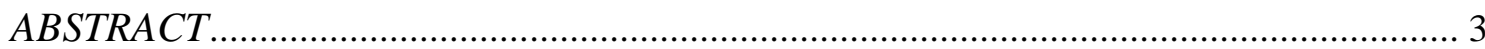

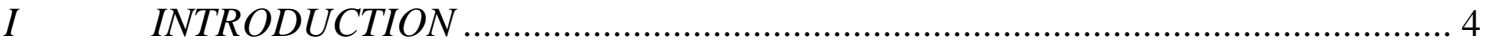

II AN INTRODUCTION TO HOLOCAUST DENIAL .......................................... 6

A Holocaust Deniers and What They Deny ……......................................................... 7

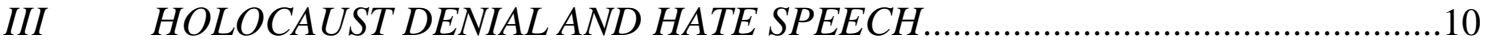

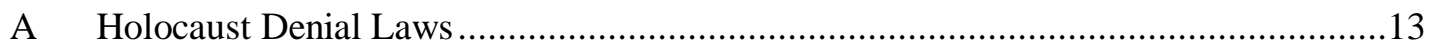

B Hate Speech Laws: Capable of Dealing with Denial? ............................................14

1 Is Holocaust Denial Consistent with Traditional Hate Speech Theory? .......15

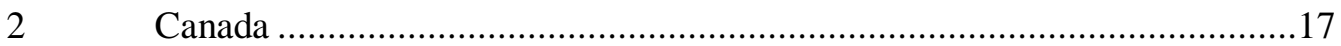

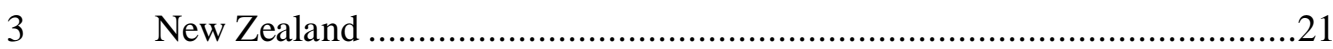

$4 \quad$ The United States of America .............................................................27

5 The Necessity of Holocaust Denial Laws in Addition to Existing Hate Speech Laws ...................................................................................... 30

IV HATE SPEECH, HOLOCAUST DENIAL, AND THE JUSTIFICATIONS FOR FREE SPEECH PROTECTION …...........................................................

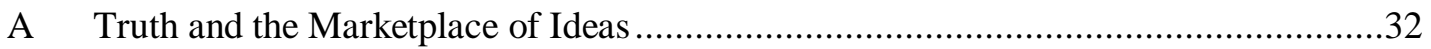

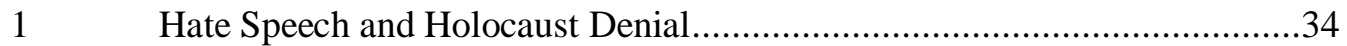

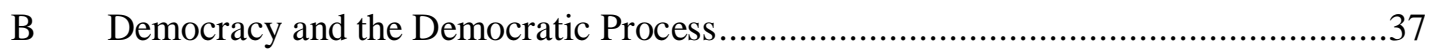

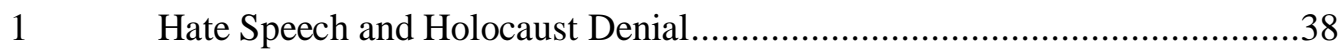

$2 \quad$ Conflict with other Democratic Values .....................................................39

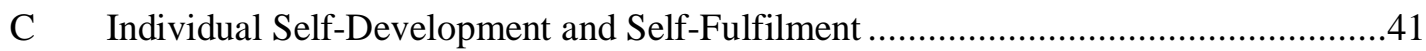

$1 \quad$ Hate Speech and Holocaust Denial.........................................................42

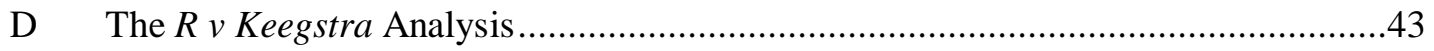

E To What Extent Should Speech That Does Not Fulfil any of the Underlying Theories of Free Speech be Protected? ........................................................................45

$V$ RECONCILING HOLOCAUST DENIAL WITH THE RIGHT TO THE

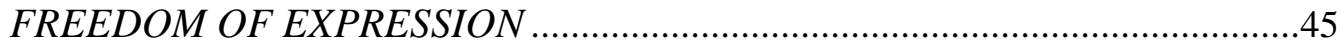

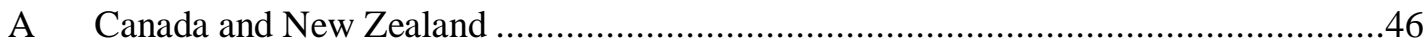

$1 \quad$ Canadian Supreme Court Application to Holocaust denial in $R v$ Keegstra (per Dickson CJ for the majority) ............................................................47

2 To what extent would Dickson CJ's analysis apply in New Zealand? .........49

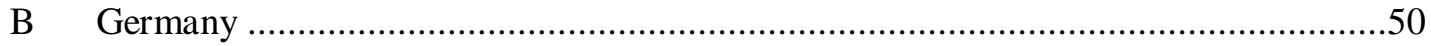

VI DENIAL AND DEFAMATION: IRVING V PENGUIN BOOKS LTD AND

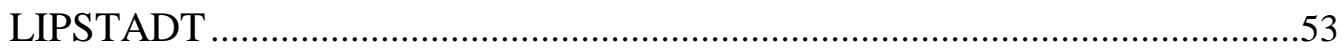

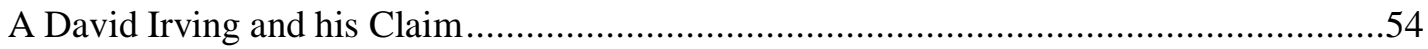

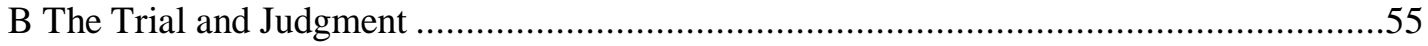

C The Significance of the Trial for Holocaust Denial .........................................................57

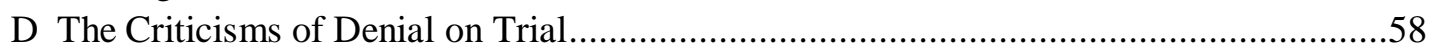

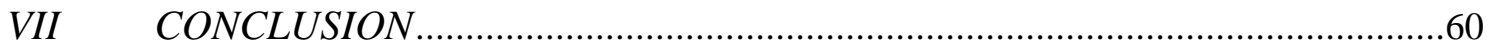

VIII APPENDIX 1: GERMAN CRIMINAL CODE ................................................63

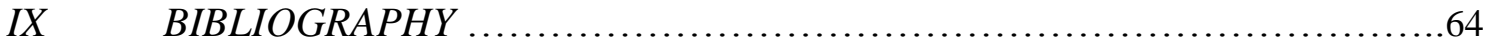




\begin{abstract}
The existence and magnitude of the largest genocide of the twentieth century, the Holocaust, are now being denied by individuals worldwide. This paper analyses the European legislation criminalising Holocaust denial from a freedom of expression perspective. The paper argues that Holocaust denial is inherently anti-Semitic, and is thus consistent with hate speech theory and the hate speech laws that have been enacted internationally in an attempt to remedy the harm hate speech can cause. The thesis of this paper is that the legislative restrictions on hate speech and Holocaust denial are justified from a free speech perspective on theoretical grounds. Such restrictions are a necessary prioritisation of human dignity and equality in the circumstances. Explicit Holocaust denial laws, while performing an essential symbolic function in European jurisdictions, are unnecessary in non-European states, as generic hate speech laws are sufficient to capture the harm caused by upper-level Holocaust denial.
\end{abstract}

\title{
Word Length
}

The text of this paper (excluding abstract, table of contents, footnotes, appendix and bibliography) comprises approximately 14,965 words.

\section{Subjects and Topics}

Holocaust Denial, or

Hate Speech, or

Freedom of Expression, or

$R v$ Keegstra, or

Irving v Penguin Books Ltd and Lipstadt. 


\section{Introduction}

Led by Hitler during the Third Reich, the Nazis drafted and executed the Final Solution to the Jewish Question. Through mobile killing squads and gas chambers at concentration camps, Jews were specifically targeted and systematically killed across Europe during the Second World War. What was the largest mass genocide of the twentieth century is referred to as the Holocaust. Though it took place only seventy years ago, a small section of the public is now denying the historically accepted facts of the Holocaust.

Despite being one of most well documented events in history, ${ }^{1}$ and almost unanimously accepted as historical fact, Holocaust denial is a "global and growing phenomenon". 2 Inextricably linked to this phenomenon is a documented worldwide increase in antiSemitism. ${ }^{3}$ For these overlapping reasons, Holocaust denial is a unique form of expression in that it can be framed in two ways: first, as false speech, and second, as anti-Semitic hate speech. Holocaust denial is hate speech because it implicitly or explicitly portrays Jews as conspirators, who orchestrated the 'hoax' of the Holocaust to gain sympathy for their own pecuniary and political benefit. While there is an inextricable overlap between the two types of speech in this context, the most persuasive rejection of Holocaust denial is through its relationship with hate speech.

Holocaust denial is interesting from a legal perspective as it highlights the direct conflicts that exist between fundamental human rights: specifically, the right to freedom of expression and the protection of human dignity. The criminalisation of Holocaust denial by European states is partly an attempt to limit the harms denial can cause. While

\footnotetext{
${ }^{1}$ Lawrence Douglas "Policing the Past: Holocaust Denial and the Law" in Robert C Post (ed) Censorship and Silencing: Practices of Cultural Regulation (Getty Research Institute, Los Angeles, 1998) 70 at 70.

${ }^{2}$ Kenneth Lasson "Defending Truth: Holocaust Denial in the Twenty-First Century" in Ludovic Hennebel and Thomas Hochmann (ed) Genocidal Denials and the Law (Oxford University Press, New York, 2011) 109 at 113.

3 Dominic McGoldrick and Therese O'Donnell "Hate Speech Laws: Consistency with National and International Human Rights Law" (2006) 18 LS 453 at 453.
} 
prosecutions under denial laws are relatively infrequent, ${ }^{4}$ these laws have further symbolic importance, and are indicative of society's intolerance towards racist hate speech. Hate speech laws have been used to successfully prosecute Holocaust denial in the absence of explicit denial laws. These laws are further evidence of the international legislative trend towards the introduction of permissible restrictions on the freedom of expression.

The thesis of this paper is that legislative restrictions on hate speech and Holocaust denial are justified on theoretical grounds. Such restrictions are a necessary prioritisation of human dignity and equality over absolute free speech in limited circumstances. Explicit Holocaust denial laws, while performing an essential symbolic function in European jurisdictions, are unnecessary in non-European states, as generic hate speech laws are sufficient to capture the harm caused by upper-level Holocaust denial.

Parts II and III of this paper introduce Holocaust denial and outline the fundamentals of denial laws, providing examples of denial prosecutions in Germany. Hate speech laws in Canada and New Zealand are analysed to determine how consistent Holocaust denial is with traditional hate speech theory. The extent to which Holocaust denial would be considered hate speech in New Zealand under the Human Rights Act 1993 (HRA) is unclear, though it is argued that some Holocaust denial could reach this threshold.

Part IV discusses the three rationales underlying free speech protection: the marketplace of ideas, democracy and individual self-fulfilment. The paper argues that hate speech and Holocaust denial are inconsistent with these free speech justifications, and thus the restrictions hate speech regulation and Holocaust denial laws impose can be defended on theoretical grounds. The Canadian case of $R v$ Keegstra $^{5}$ is analysed as a practical application of these three theories.

\footnotetext{
${ }^{4}$ Julie C Suk "Denying Experience: Holocaust Denial and the Free-Speech Theory of the State" in Michael Herz and Peter Molnar (eds) The Content and Context of Hate Speech: Rethinking Regulation and Responses (Cambridge University Press, New York, 2012) 144 at 151.

${ }^{5}$ [1990] 3 SCR 697.
} 
Part V compares the approaches taken in Canada and Germany when reconciling competing fundamental rights. It is argued that the weight given to different rights necessarily varies depending on the social and historical context within which the nations operate.

Part VI canvases the English defamation trial of Irving $v$ Penguin Books Ltd and Lipstadt. ${ }^{6}$ The case illuminates the significance Holocaust denial has in other areas of law, and reiterates in a judicial setting the anti-Semitic motivations of Holocaust deniers. The paper discusses the criticisms of denial on trial, but argues these concerns should not be overstated, given the publicity deniers receive is overwhelmingly negative, and the capacity of the laws to serve as a declaration of society's intolerance of racial hatred.

\section{An Introduction to Holocaust Denial}

The precise definition of Holocaust denial is the subject of debate. Not merely limited to outright denial, Holocaust denial encompasses justification, minimisation, negation and distortion of the Holocaust. ${ }^{7}$ Modern Holocaust denial comprises three basic propositions: First, while acknowledging that Jews were killed during World War II, deniers assert that there was no official Nazi policy to systematically exterminate the Jews. ${ }^{8}$ Rather, the policy was one of deportation and resettlement. ${ }^{9}$ Second, they assert that the gas chambers at Auschwitz and other concentration camps were not used for killing, but for the fumigation of clothing. ${ }^{10}$ Third, deniers argue that the number of Jews killed during World War II was

\footnotetext{
${ }^{6}$ [2000] EWHC QB 115 (see trial transcript, The Nizkor Project "Irving vrs. Lipstadt" <www.nizkor.org>), herein referred to as Irving $v$ Lipstadt.

${ }^{7}$ Examples include Paul Rassinier The Drama of the European Jews (Steppingstones Publications, Maryland, 1975); Arthur Butz The Hoax of the Twentieth Century: The Case Against the Presumed Extermination of European Jewry (Theses \& Dissertation Press, Chicago, 1976); Austin App The Six Million Swindle (Boniface Press, Tacoma Park, 1973).

${ }^{8}$ Andrew E Mathis "Holocaust Denial, a Definition" The Holocaust History Project <www.holocausthistory.org>; App, above n 7, at 18; Peter Knight Conspiracy Theories in American History: An Encyclopedia (ABC-CLIO, California, 2003) at 321; Lasson, above n 2, at 113.

${ }^{9}$ Butz, above $\mathrm{n} 7$.

${ }^{10}$ Mathis, above n 8; App, above n 7, at 18; Knight, above n 8, at 321.
} 
significantly less than the historically accepted total of six million, and was in fact anywhere between 200,000 and 1.5 million. $^{11}$

While many who assert these propositions refer to themselves as Holocaust "revisionists", for the purposes of this paper they will be referred to as Holocaust deniers. The term "revisionism" suggests a level of academic credibility. The facts of the Holocaust have been proven by documentary evidence, innumerable eye witness accounts, and in several international courts and tribunals. While many deniers would argue that they are historians engaged in legitimate historical inquiry, this is somewhat misguided, given the predominant motive of deniers is to disparage the Jewish community. The term Holocaust deniers is thus deemed more appropriate.

\section{A Holocaust Deniers and What They Deny}

Holocaust denial, while originating in Europe, has international support. ${ }^{12}$ This Part of the paper proposes to briefly provide examples of deniers worldwide, to illustrate the pervasiveness of Holocaust denial. The first major United States Holocaust denier was Austin App, a German-American Professor, who published The Six Million Swindle in 1973. ${ }^{13}$ The article is strongly anti-Semitic, and puts forward eight "incontrovertible points" in denial of the Holocaust. App asserted: “... the charge that Hitler and the Third Reich wanted to exterminate all Jews is a totally fabricated, brazen lie!"14 In regards to the accepted quantum of Jewish deaths during the War, App declared this a result of "guess work" and "shameful unreliability". ${ }^{15}$ App's work, which was published in several magazines and newspapers, inspired the establishment of the Institute for Historical Review (IHR).

\footnotetext{
${ }^{11}$ Mathis, above n 8; App, above n 7, at 18; Knight, above n 8, at 321.

12 Deborah E Lipstadt Denying the Holocaust: The Growing Assault on Truth and Memory (Penguin, New York, 1993).

${ }^{13}$ App, above $n 7$.

14 App, above n 7, at 3.

15 App, above n 7, at 15 .
} 
The IHR, established in 1978 with the purpose of denying facts of the Nazi regime, has labelled the Holocaust a "Holohoax". ${ }^{16}$ According to their website, the Institute's mission is to promote peace and justice through a better understanding of the past, particularly the nature of twentieth century war and conflict. ${ }^{17}$ Founding members of the Institute describe themselves as "vigorous" defenders of the right to freedom of expression and the right to conduct independent historical inquiry. ${ }^{18}$ The Institute has received international criticism as an anti-Semitic, "pseudo-academic" organisation with neo-Nazi affiliations. ${ }^{19}$

Perhaps the most notorious Holocaust denier is English writer, David Irving. Irving has published approximately 30 books on Hitler and the Second World War and has delivered several lectures "revising" the Holocaust. ${ }^{20}$ In an interview for Italian television, Irving declared that Auschwitz was nothing but a "tourist attraction [that] did not have gas chambers", ${ }^{21}$ and was an "ingenious plan" of the British Psychological Warfare Executive to spread anti-German propaganda. ${ }^{22}$ Irving appeared as a witness during the Canadian Holocaust denial trial of Ernst Zundel. ${ }^{23}$ He gained further notoriety during the English defamation trial, Irving $v$ Penguin Books Ltd and Lipstadt. ${ }^{24}$ The imprisonment of Irving (for charges under Austrian Holocaust denial laws) led to a temporary break in Holocaust denial activity. Since his release, however, denial has "substantially increased"

\footnotetext{
${ }^{16}$ Richard Evans Lying About Hitler: History, Holocaust and the David Irving Trial (Basic Books, New York, 2002) at 148; Michael Shermer and Alex Grobman Denying History: Who Says the Holocaust Never Happened and Why do they say it (Updated and expanded edition, University of California Press, Los Angeles, 2000) at 10; Anti-Defamation League "Extremism in America: Institute for Historical Review" <www.archive.adl.org>.

${ }^{17}$ Institute for Historical Review “About the IHR: Our Mission and Record” (April 2010) <www.ihr.org>.

${ }^{18}$ Institute for Historical Review, above n 17.

${ }^{19}$ Russ Bellant Old Nazis, the New Right, and the Republican Party: Domestic Fascist Networks and their Effect on US Cold War Politics (3rd ed, South End Press, Boston, 1991) at 43; Anti-Defamation League, above n 16; Princeton University "Institute for Historical Review < www.princeton.edu>.

${ }^{20}$ See for example David Irving Hitler's War (Hodder \& Stoughton, London, 1977); David Irving The War Path (The Viking Press, New York, 1978).

${ }^{21}$ Lasson, above $\mathrm{n}$ 2, at 114.

${ }^{22}$ Robert J Van Pelt The Case for Auschwitz: Evidence from the Irving Trial (Indiana University Press, Indiana, 2002) at 48.

${ }^{23} R$ v Zundel [1992] 2 SCR 731, see Part III.

${ }^{24}$ Above n 6, see Part VI.
} 
worldwide. ${ }^{25}$ Arguably, this increase is representative of Irving's influence within far-right denial circles.

The controversy surrounding New Zealand historian, Joel Hayward, raised the issue of Holocaust denial in New Zealand. In 1993, Hayward received an A+ from the University of Canterbury for his Master of Arts thesis on Holocaust revisionism. ${ }^{26}$ Hayward came to the conclusion that there was no evidence of an official Nazi policy to exterminate the Jews, that homicidal gas chambers were merely "atrocity propaganda", and that significantly less than six million Jews were killed during World War II. ${ }^{27}$

In 2000 , the thesis became publically available, causing "unprecedented" controversy. ${ }^{28}$ The New Zealand Jewish Council requested that the University establish a Working Party to determine how Hayward was awarded first class honours for his paper, requesting Hayward's Master of Arts qualification be revoked. ${ }^{29}$ The Working Party concluded that the paper was "seriously flawed" by "methodological failures", and recommended that the University issue an apology to the Jewish Council. ${ }^{30}$ Despite this, Hayward was not stripped of his degree. While Hayward conceded in his Addendum to the paper the errors of fact and judgment made, ${ }^{31}$ David Irving has praised Hayward's work as a "landmark in

\footnotetext{
${ }^{25}$ Lasson, above $\mathrm{n} 2$, at 114.

${ }^{26}$ The paper was titled "The Fate of Jews in German Hands: An Historical Enquiry Into the Development and Significance of Historical Revisionism".

${ }^{27}$ As discussed in the Joel Hayward Working Party "Report to the Council of the University of Canterbury of the Working Party established to enquire into: the circumstances under which the degree of Master of Arts (with First Class Honours) was awarded by the University in 1993 to Joel Stuart Andrew Hayward, on the basis of a thesis entitled 'The Fate of Jews in German Hands: An Historical Enquiry into the Development and Significance of Historical Revisionism" (20 December 2000) University of Canterbury <www.canterbury.ac.nz> at 62 .

${ }^{28}$ Jessica Caldwell "Holocaust Consciousness in New Zealand 1980-2010: A Study" (Master of Arts thesis, Victoria University of Wellington, 2011) at 56.

${ }^{29}$ University of Canterbury "Hayward Thesis Working Party" < www.canterbury.ac.nz>.

${ }^{30}$ Joel Hayward Working Party "Report by the Joel Hayward Working Party: Executive Summary" (20 December 2000) University of Canterbury <www.canterbury.ac.nz> at 10, 11 and 17.

31 Joel Hayward "Addendum: The Fate of Jews in German Hands: An Historical Enquiry into the Development and Significance of Historical Revisionism" (26 January 2000) University of Canterbury <www.canterbury.ac.nz>.
} 
the turning of the tide in favour of historical revisionism." 32 This is illustrative of the pervasive, international influence of "revisionist" works, and their capacity to jeopardise legitimate historical development.

Later incidents at Waikato University reiterated the impact of Holocaust denial in New Zealand. Hans Joachim Kupka, who had been planning his $\mathrm{PhD}$ on the German language, was found to have made frequent postings of Holocaust denial in a far-right online forum. Controversially, New Zealand is the only nation where a Master's degree has been awarded for a paper on Holocaust denial. Caldwell argues that this peculiarity is a result of New Zealand's "apathetic attitude" towards the Holocaust, and strong constitutional protection of the right to freedom of expression. ${ }^{33}$

The prevalence of denial worldwide triggered legal intervention prohibiting Holocaust denial and hate speech.

\section{Holocaust Denial and Hate Speech}

Holocaust denial laws are controversial, provoking legal and historical debate. Many jurisdictions that do not have laws explicitly criminalising Holocaust denial have hate speech legislation, but whether hate speech laws could encompass denial is the subject of debate. This Part engages in that debate by providing an overview of explicit Holocaust denial laws, and then analyses hate speech legislation in Canada and New Zealand to determine the consistency of Holocaust denial with these laws.

The most persuasive argument in favour of Holocaust denial laws is on the basis that Holocaust denial is a form of hate speech, and thus should be restricted. Hate speech involves insults or denigration directed at a particular group of people, based on a shared

\footnotetext{
32 As cited in Sean Scanlon "Making History" The Press (Christchurch, 20 May 2000).

${ }^{33}$ Above n 28, at 74.
} 
characteristic of that group (such as race, religion, ethnicity or sexual orientation). ${ }^{34}$ Usually, the speech is targeting an 'immutable' characteristic, and thus is one the victims have no power to change. ${ }^{35}$ Hate speech is criminalised because of the perceived harm it causes or has the capacity to cause. ${ }^{36}$ Specifically, hate speech degrades its victims, and can cause severe physical and psychological harm. ${ }^{37}$ Thus, hate speech goes far beyond offensive speech, or mere dislike for a group. ${ }^{38}$ It is intended to capture the upper level of degrading and hostile speech. ${ }^{39}$

Hate speech causes harm not just to individuals, but also to society at large. Primarily, hate speech exacerbates existing inequalities in a community, ${ }^{40}$ through the vilification and persecution of minority groups. Victims in minority groups suffer stigmatisation and

\footnotetext{
${ }_{34}$ Douglas M Fraleigh and Joseph S Tuman Freedom of Expression in the Marketplace of Ideas (SAGE, California, 2011) at 139; Raphael Cohen-Almagor "Hate in the Classroom: Free Expression, Holocaust Denial and Liberal Education" (2007) 114 American Journal of Education 215 at 215; Andrew Butler and Petra Butler The New Zealand Bill of Rights Act: A Commentary (LexisNexis, Wellington, 2005) at 364; Laura Leets "Experiencing Hate Speech: Perceptions and Responses to Anti-Semitism and Antigay Speech" (2002) 58 J of Social Science Issues 341 at 342; Steven J Heyman Free Speech and Human Dignity (Yale University Press, New Haven, 2008) at 164; Richard Moon The Constitutional Protection of Freedom of Expression (University of Toronto Press, Toronto, 2000) at 126.

${ }^{35}$ Fraleigh and Tuman, above n 34, at 140.

${ }^{36}$ Ionna Tourkochoriti "Should Hate Speech Be Protected? Group Defamation, Party Bans, Holocaust Denial and the Divide between (France) Europe and the United States" (2014) 45 Colum Hum Rts L Rev 552 at 598 ; Susanne Baer "Violence: Dilemmas of Democracy and Law" in David Kretzmer and Francine Kershman Hazan (eds) Freedom of Speech and Incitement Against Democracy (Kluwer Law International, The Hague, 2000) 63 at 74; Heyman, above n 34, at 165.

${ }^{37}$ Nicholas Wolfson Hate Speech, Sex Speech, Free Speech (Praeger Publishers, Connecticut, 1997) at 2; Fraleigh and Tuman, above n 34, at 140; Mari Matsuda "Public Responses to Racist Speech: Considering the Victim's Story" (1989) 87 Mich L Rev 2320 at 2332; Cohen-Almagor, above n 34, at 218; C Edwin Baker "Autonomy and Hate Speech" in Ivan Hare and James Weinstein (eds) Extreme Speech and Democracy (Oxford University Press, New York, 2009) 139 at 156.

${ }^{38}$ Moon, above $\mathrm{n} 34$, at 127.

${ }^{39}$ Bhikhu Parekh "Is There a Case for Banning Hate Speech" in Michael Herz and Peter Molnar (eds) The Content and Context of Hate Speech: Rethinking Regulation and Responses (Cambridge University Press, New York, 2012) 37 at 40; Holger Reinhardt "The Harm of Holocaust Denial v the Freedom of Expression: Hate Speech, and the Legal Response and the Search for a Universal Solution to a Universal Problem" (LLB (Hons) thesis, Victoria University of Wellington, 2011) at 12.

${ }^{40}$ See Fraleigh and Tuman, above n 34, at 162; Tourkochoriti, above n 36, at 598.
} 
disempowerment, ${ }^{41}$ which can develop into feelings of isolation and self-doubt. ${ }^{42}$ Furthermore, there is an inextricable connection between hate speech and the commission of hate crimes. ${ }^{43}$ The existence of hate speech, therefore, contributes to a more dangerous and violent society.

Holocaust denial is a manifestation of anti-Semitic motivations. Deniers are attempting to reduce the sympathy towards Jews arising out of the Holocaust, and are challenging the legitimacy of the State of Israel and Jewish suffering. ${ }^{44}$ Therefore, it is argued that Holocaust denial is an attempt to vilify and bring into disrepute the Jewish people, consistent with the definition of hate speech. ${ }^{45}$ Holocaust denial is inherently racist, ${ }^{46}$ and while it exists as a separate issue, it largely overlaps with hate speech considerations. ${ }^{47}$ While European states have criminalised denial partly to thwart the resurgence of

${ }^{41}$ See Katharine Gelber Speaking Back: The free speech versus hate speech debate (John Benjamins Publishing, Philadelphia, 2002) at 1-2; Ishani Maitra and Mary Kate McGowan "Introduction" in Ishani Maitra and Mary Kate McGowan Speech and Harm: Controversies Over Free Speech (Oxford University Press, Oxford, 2012) 1 at 5.

${ }^{42}$ See Benjamin Baez Affirmative Action, Hate Speech and Tenure: Narratives About Race and Law in the Academy (Routledge, New York, 2013) at 46-47; Wojciech Sadurski Freedom of Speech and Its Limits (Kluwer Academic Publishers, Massachusetts, 1999) at 195.

${ }^{43}$ Alan Allport Freedom of Speech (Chelsea House, Philadelphia, 2003) at 25; Michael Whine "Expanding Holocaust Denial and Legislation Against It" in Ivan Hare and James Weinstein (eds) Extreme Speech and Democracy (Oxford University Press, New York, 2009) 539 at 543; Anthony Cortese Opposing Hate Speech (Praeger, Connecticut, 2006) at 137; Alexander Tsesis "Dignity and Speech: The Regulation of Hate Speech in a Democracy" (2009) 44 Wake For L Rev 497 at 516; Butler and Butler, above n 34, at 364; Juliet Moses "Hate Speech: Competing Rights to Freedom of Expression" (1996-1999) 8 Auckland U L Rev 185 at 195; Raphael Cohen-Almagor "Holocaust Denial is a Form of Hate Speech" (2009) 2 Amsterdam L Forum 33 at 37.

${ }^{44}$ See United States Holocaust Memorial Museum "Holocaust Denial and Distortion" < www.ushmm.org>; Frederick Schauer "Social Epistemology, Holocaust Denial and the Post-Millian Calculus" in Michael Herz and Peter Molnar (eds) The Content and Context of Hate Speech: Rethinking Regulation and Responses (Cambridge University Press, New York, 2012) 129 at 141, Suk, above n 4, at 144; Anti-Defamation League "Holocaust Denial: An Online Guide to Exposing and Combating Anti-Semitic Propaganda" <www.archive.adl.org>; Cohen-Almagor, above n 43, at 36.

${ }^{45}$ See Jeremy Jones “Holocaust Denial: 'Clear and Present' Racial Vilification” (1994) 10 AJHR 169.

${ }^{46}$ Raphael Cohen-Almagor, above n 34, at 216.

${ }^{47}$ James Weinstein and Ivan Hare "General Introduction: Free Speech, Democracy, and the Suppression of Extreme Speech Past and Present" in Ivan Hare and James Weinstein (eds) Extreme Speech and Democracy (Oxford University Press, New York, 2009) 1 at 4. 
Nazism, ${ }^{48}$ criminalisation of Holocaust denial is now seen as consistent with laws against racial and religious hatred. ${ }^{49}$

\section{A Holocaust Denial Laws}

Explicit or implicit Holocaust denial laws exist in 14 countries. International instruments contain provisions relating to genocide denial. ${ }^{50}$ The only non-European jurisdiction to criminalise Holocaust denial is the State of Israel. The proliferation of the creation of these laws in Europe began in the 1960s, to combat the resurgence of anti-Semitism. ${ }^{51}$ While some laws deal explicitly with the Holocaust or National Socialist genocide, ${ }^{52}$ others refer to the denial of genocide or war crimes more broadly. ${ }^{53}$

Unsurprisingly, the most punitive Holocaust denial laws exist in Germany and Austria. ${ }^{54}$ This is largely because of the embarrassment these nations face as a result of their role in the perpetration of the Holocaust. Further, there is a desire to thwart the rise of neo-Nazi movements. ${ }^{55}$ The Federal Republic of Germany was founded as an "ideological repudiation of the Nazis" ${ }^{56}$ Holocaust denial poses a threat to the ideologies of Germany,

\footnotetext{
${ }^{48}$ Whine, above n 43, at 543; Michael J Bazyler "Holocaust Denial Laws and Other Legislation Criminalizing Promotion of Nazism" (Podcast, 25 December 2006) Yad Vashem < www.yadvashem.com> at 1.

${ }^{49}$ European Commission "Report from the Commission to the European Parliament and the Council on the implementation of Council Framework Decision 2008/913/JHA on combating certain forms and expressions of racism and xenophobia by means of criminal law" (2014) 27.

${ }^{50}$ See for example European Union Framework Decision for Combating Racism and Xenophobia.

${ }^{51}$ Robert A Kahn "Holocaust Denial and Hate Speech" in Ludovic Hennebel and Thomas Hochmann (eds) Genocidal Denials and the Law (Oxford University Press, New York, 2011) 77 at 80.

${ }^{52}$ As at 27 September 2014: Austria, Belgium, Czech Republic, France, Germany, Hungary, Israel, Lithuania, Luxembourg, Poland and Romania.

53 As at 27 September 2014: Liechtenstein, Portugal and Switzerland (translated by Michael Whine "Expanding Holocaust Denial and Legislation Against It" (2008) 20 Jewish Pol Studies Rev 1.

${ }^{54}$ A maximum sentence of imprisonment of five years and twenty years respectively.

${ }^{55}$ Whine, above $\mathrm{n} 43$, at 543.

${ }^{56}$ Kahn, above n 51, at 78; Rainer Erb "Public Responses to Antisemitism and Right-Wing Extremism" in Hermann Kurthen, Werner Bergmann and Rainer Erb (eds) Antisemitism and Xenophobia in Germany after Unification (Oxford University Press, Oxford, 1997) 211 at 218.
} 
and denial laws are an implicit rejection of neo-Nazism. The German Criminal Code criminalises public incitement under s $130 .{ }^{57}$

Broadly, s 130(1) could be considered the criminalisation of hate speech. More specifically, subss (3) and (4) criminalise public Holocaust denial. The type of expression that is criminalised by subs (4) requires an assault against the human dignity of the victims. Both subss (1) and (3) dictate that the expression must be "in a manner that is capable of disturbing the public peace", and subs (4) requires the public peace be disturbed in actual fact. Intent to harm others is not required under the section. ${ }^{58}$

German Holocaust deniers, Ernst Zundel and Horst Mahler, both received sentences of five years imprisonment under this Code. ${ }^{59}$ Mahler, aged 78, is a German former lawyer and political activist. Mahler is currently serving a 12-year prison sentence for Holocaust denial and other related public incitement charges, and the banalisation of Nazi war crimes. Prosecutions such as these demonstrate the highly punitive nature of Holocaust denial laws in Germany. However, as demonstrated by Mahler's numerous convictions, it can be argued that these laws do not serve as an effective deterrent against denial activity.

\section{B Hate Speech Laws: Capable of Dealing with Denial?}

In absence of explicit Holocaust denial laws, many jurisdictions have enacted laws criminalising hate speech more broadly. This section will analyse the ability of these generic hate speech laws to effectively address Holocaust denial. This inquiry is necessary to determine whether hate speech laws are sufficient in non-European jurisdictions to encompass the harms of denial.

\footnotetext{
${ }^{57}$ See Appendix 1 for the full text: German Criminal Code, s 130(1) (translated by Legislation online "Criminal Code of the Federal Republic of Germany English version" < www.legislationonline.com>.

${ }^{58}$ Sebastian Hoegl "Holocaust Denial: One's Free Expression of Thought or Just Hate Speech?" (LLM Research Paper, Victoria University of Wellington, 2008) at 30.

59 "Holocaust denier in Germany sentenced to five years in prison - Europe - International Herald Tribune" The New York Times (online ed, 15 February 2007).
} 


\section{Is Holocaust Denial Consistent with Traditional Hate Speech Theory?}

Holocaust denial is widely considered a subset of hate speech. ${ }^{60}$ Not only does it deny survivors their history, ${ }^{61}$ it is inherently anti-Semitic, ${ }^{62}$ and is thus a willful attack against Jews based on racial grounds. In this way, Holocaust denial can be viewed as anti-Jewish propaganda. Reich argues: ${ }^{63}$

The primary motivation for most deniers is anti-Semitism, and for them the Holocaust is an infuriatingly inconvenient fact of history. ... What better way to rehabilitate anti-Semitism ... than by convincing the world that the great crime for which anti-Semitism was blamed simply never happened.

While the majority of academics consider Holocaust denial a type of hate speech, some consider denial to be more complex, arguing that hate speech theory does little to "capture the harm" of denial. ${ }^{64}$

This raises the question of whether non-specific, generic hate speech laws are capable of dealing with the unique nature of Holocaust denial. While it is accepted that denial is inherently anti-Semitic, denial differs from traditional hate speech in that the speech is not always targeting an individual based on their Jewish characteristics; much denial is more subtle than that. Further, in criminalising Holocaust denial, there is an inherent danger in thwarting more legitimate historical inquiry, a danger absent from most other hate speech considerations. Teachout captures the distinction: ${ }^{65}$

\footnotetext{
${ }^{60}$ See Lasson, above n 2, at xix; Cohen-Almagor, above n 43; Cohen-Almagor, above n 34, at 216; Whine, above $\mathrm{n} 43$, at 542 .

${ }^{61}$ Comment of Arthur Berney in Gerald Tishler "Debate: Freedom of Speech and Holocaust Denial" (19861987) 8 Cardozo L Rev 559 at 573.

${ }^{62}$ Jones, above n 45; David Fraser “'On the Internet, Nobody Knows You're a Nazi': Some Comparative Legal Aspects of Holocaust Denial on the WWW" in Ivan Hare and James Weinstein (eds) Extreme Speech and Democracy (Oxford University Press, New York, 2009) 511 at 519.

${ }^{63}$ Walter Reich "Erasing the Holocaust” New York Times Book Review (online ed, 11 July 1993).

${ }^{64}$ Kahn, above n 51, at 77.

${ }^{65}$ Peter Teachout "Making 'Holocaust Denial' a Crime: Reflections on European Anti-Negationist Laws from the Perspective of US Constitutional Experience" (2006) 30 Vt L Rev 655 as cited in Christopher Bishop
} 
It is one thing to say a state may legitimately censor and punish speech that serves to incite racial suspicion and hatred under a law that makes that factor the central determining element; it is quite another to say a state may censor and punish the exact same speech because the views expressed fail to conform to some state-established, orthodox version of history.

Debate over whether Holocaust denial is a type of hate speech largely centres around the distinction frequently made between "bare" (or "simple") denial and "aggressive" denial. What these distinctions are attempting to encapsulate is that the definition of Holocaust denial is fluid, and exists along a spectrum. Bare denial is similar to quantitative minimisation, for example, assertions that the quantum of Jewish deaths during the War was 200,000, without making a direct, targeted attack against the Jewish people. Aggressive denial would go further, for example, statements that the Holocaust is a conspiracy theory created by the Jews to gain sympathy and financial advantage.

While widely accepted that "aggressive" denial is a form of anti-Semitic hate speech, ${ }^{66}$ whether bare denial is hate speech is more arguable. Perhaps "bare" Holocaust denial, whilst historically inaccurate, does not necessarily contain denigrating or threatening words in the traditional sense. ${ }^{67}$ However, many forms of bare denial would be considered hate speech. ${ }^{68}$ Not all hate speech is transparent. ${ }^{69}$ By arguing, without more, that only 200,000 Jews were killed during the War, deniers may be implying that the Jewish people were involved in a conspiracy, by misrepresenting or exaggerating the effects of the War on Jews to advance Jewish interests. ${ }^{70}$ Without constituting a direct or targeted attack, this "minimisation" or "negation" is inherently anti-Semitic, detracts from Jewish suffering, and is an assault on their dignity, consistent with traditional hate speech theory.

\footnotetext{
"Denying the Undeniable: Holocaust Denial, the Criminal Law, and Free Speech" (LLB (Hons) Research Paper, Victoria University of Wellington, 2007) at 25.

${ }^{66}$ See Lasson, above n 2, at xix.

${ }^{67}$ Kahn, above n 51, at 84-85.

${ }^{68}$ See Parekh, above n 39, at 41-42.

${ }^{69}$ See Parekh, above n 39, at 41.

${ }^{70}$ United States Holocaust Memorial Museum, above n 44.
} 
Further, Holocaust denial is a subset of hate speech because of the detrimental effects an environment of anti-Semitism has on society generally. Holocaust denial can operate to demean the existence of Jews, thus fostering an atmosphere of distrust and discrimination. In having this effect on the Jewish community, denial is "a precursor to subordination, diminishment and ultimately the destruction of a people." 71 This in turn engenders inequality in society.

Hate speech legislation and cases in different jurisdictions will be examined to determine the consistency of Holocaust denial with traditional hate speech theory.

\section{Canada}

Canada has witnessed a surprisingly high level of Holocaust denial activity. While not explicitly criminalising denial, hate speech legislation in Canada has been used to successfully prosecute Holocaust deniers. Section 319(2) of the Canadian Criminal Code makes the willful promotion of hatred against any identifiable group, other than in private conversation, an indictable offence. The enactment of this provision indicated that the Canadian Parliament was proactively denouncing racist hate speech, consistent with its obligations under art 4 of ICERD. ${ }^{72}$

James Keegstra was a high school history teacher in Alberta, Canada. Keegstra taught his students that Jews were "treacherous", "sadistic", "money-loving", "child-killers", and that they "seek to destroy Christianity and are responsible for depressions, anarchy, chaos, wars and revolution." ${ }^{, 73}$ Keegstra was charged under s 319(2) of the Code and initially convicted in the Alberta Court of Queen's Bench. ${ }^{74}$ The Alberta Court of Appeal, on the basis of a constitutional challenge to s $319(2)$, overturned the conviction. ${ }^{75}$ The Government

\footnotetext{
${ }^{71}$ Tishler, above n 61, at 572.

${ }^{72}$ International Covenant on the Elimination of All Forms of Racial Discrimination, see Luke McNamara Human Rights Controversies: The Impact of Legal Form (Routledge-Cavendish, London, 2007).

${ }^{73} R v$ Keegstra, above n 5, at 714.

${ }^{74} R v$ Keegstra (1984) 19 CCC (3d) 254.

${ }^{75} R v$ Keegstra (1988) 60 Alta LR (2d) 1.
} 
appealed the result to the Supreme Court of Canada, who upheld the constitutionality of s $319(2)$ by a narrow majority of $4-3 .^{76}$

The issue in the Supreme Court was the constitutional validity of s 319(2). ${ }^{77}$ The Court held that the prohibition of hate speech codified in s 319(2) was contrary to s 2(b) of the Canadian Charter of Rights and Freedoms, which states that everyone has the fundamental right to the freedom of expression. While at first blush this seems obvious, the declaration by the Court is significant. The Court is acknowledging that hate speech is a "meaningful" form of communication, ${ }^{78}$ creating a presumption is favour of free speech, in approval of the broad scope intended by s 2 (b). ${ }^{79}$ With regards to hate speech, the Court ruled: ${ }^{80}$

\begin{abstract}
Hatred is predicated on destruction, and hatred against identifiable groups therefore thrives on insensitivity, bigotry and destruction of both the target group and of the values of our society. Hatred ... if exercised against members of an identifiable group, implies that those individuals are to be despised, scorned, denied respect and made subject to ill-treatment on the basis of group affiliation.
\end{abstract}

Thus, the Court held that Holocaust denial was a form of hate speech and harmed individual victims and society generally. ${ }^{81}$ The Court held that the evidence established that Keegstra "systematically denigrated Jews and Judaism" during his classes. ${ }^{82}$ This dicta is consistent with traditional hate speech theory. The decision in $R v$ Keegstra largely resolved many of the issues surrounding the legitimacy of hate speech legislation, particularly the constitutional validity of such legislation when up against freedom of expression considerations. ${ }^{83}$

\footnotetext{
76 Dickson CJ and Wilson, L'Heureux-Dube and Gonthier JJ for the majority; La Forest, Sopinka and McLachlin JJ dissenting.

77 At 713.

${ }^{78}$ Hilliard Aronovitch “The Harm of Hate Propaganda” in Manjunath Pendakur and Roma M Harris (eds) Citizenship and Participation in the Information Age (Garamond Press, Ontario, 2002) 147 at 151.

${ }^{79}$ Aronovitch, above n 78, at 151.

80 At 777.

${ }^{81}$ At 745.

82 At 797.

${ }^{83}$ A deeper analysis of the balancing exercise undertaken by the Court will be the subject of Part V.
} 
However, a decision of the same court concerning a different provision of the Criminal Code overturned the defendant's conviction for Holocaust denial. ${ }^{84}$ Ernst Zundel was indicted for two charges relating to his publication of "The West, War and Islam" and Did Six Million Really Die ${ }^{85}$ The former argued that there was an international Jewish conspiracy to control the world through bankers and communists, and the latter argued that the Holocaust was a "fraud" and the largest deception in history. ${ }^{86}$ Rather than being charged under s 319(2) of the Code, Zundel was charged under s 181, for the willful publication of false information likely to cause injury or mischief to a public interest. ${ }^{87}$ In making the case, the Crown argued that a segment of the Canadian population were being targeted and stigmatised, contrary to the public interest in the maintenance of social and racial tolerance. ${ }^{88}$

Controversially, Judge Hugh Locke in the lower court declined to take judicial notice of the Holocaust, in fairness to the defendant, as it would have given the prosecution an advantage in proving their case. ${ }^{89}$ The judgment was appealed to the Ontario Court of Appeal, and then to the Supreme Court of Canada. At issue was the constitutional validity of s 181 .

The eight-week appeal generated a great deal of media attention, largely due to Zundel's antics throughout. The Crown had to establish that the material published in Did Six Million Really Die? was false. Originally convicted for the publication, the Supreme Court overturned the conviction. The Court held that $\mathrm{s} 2$ of the Charter protects all expression of a non-violent form, and the content of that expression is irrelevant because s 2 (b) is content-

\footnotetext{
${ }^{84} R v$ Zundel, above n 23.

${ }^{85}$ Did Six Million Really Die? was written by Richard Verrall under the pseudonym Richard Harwood.

${ }^{86}$ Marouf A Hasian Jr "Canadian Civil Liberties, Holocaust Denial, and the Zundel Trials" (1999) 21 Communications and the Law 43 at 48.

${ }^{87}$ Section 181 was an antiquated provision enacted to deal with protecting "great men of the realm against false news or tales", and was not designed to address hate speech, see Friedman, above n 168, at 197. ${ }^{88}$ At 789.

${ }^{89}$ Hasian, above n 86, at 49; Robert A Kahn Holocaust Denial and the Law: A Comparative Study (Palgrave Macmillan, New York, 2004) at 1.
} 
neutral. It followed that s 2(b) included expression of minority beliefs, even where the majority may find those beliefs to be false. ${ }^{90}$ The limitation imposed on the right in s $2(\mathrm{~b})$ by s 181 of the Code was not justified under s 1 of the Charter. ${ }^{91}$

Therefore, the provision criminalising the spreading of false news was considered to be unconstitutional. The decision in $R v$ Zundel has been extensively criticised. The decision has been denounced as "a total victory for Holocaust deniers and a total disaster for Holocaust survivors and the Jewish people". ${ }^{92}$ Mandel warned that the decision would likely "read like, and form part of, Holocaust denial literature itself". 93

The $R v$ Keegstra and $R v$ Zundel decisions raise interesting issues for hate speech laws and Holocaust denial. These two cases demonstrate the unique nature of Holocaust denial, in that it can be framed as either hate speech or false speech (although by in large there is an inherent overlap, whereby most Holocaust denial is both hate speech and false speech). At several points throughout the $R v$ Zundel judgment, the Court makes a point of distinguishing the case from $R v$ Keegstra. The Court argued that the legislative intent behind s 181 was unclear, and, contrary to s 319(2), the aim of the section was not to encourage and promote racial and social harmony. ${ }^{94}$ Contrary to s 319(2), which is strictly confined to hate propaganda, the Court held that s 181 was too vague and wide reaching, having a potentially "undefined and virtually unlimited reach". ${ }^{95}$ Pertinently, according to McLachlin $\mathrm{J}$, the harm in $R v$ Zundel was more indirect than the harm caused in $R v$ Keegstra. ${ }^{96}$

\footnotetext{
${ }^{90}$ At 732.

${ }^{91}$ Gonthier, Cory and Iacobucci JJ dissenting.

${ }^{92}$ Kahn, above n 89, at 119.

${ }^{93}$ Michael Mandel The Charter of Rights and the Legalisation of Politics in Canada (Thompson Educational Publishing, Toronto, 1994) at 369 as cited in Kahn, above n 89, at 96.

${ }^{94}$ At 765.

${ }^{95}$ At 769.

${ }^{96}$ At 774.
} 
Zundel was indicted under s 181 of the Code rather than s 319(2) because the AttorneyGeneral, though sympathetic, refused to grant consent to prosecute, ${ }^{97}$ believing s 319 (2) to be unenforceable. ${ }^{98}$ With hindsight, it is clear that the opposite proved to be true. The fact that the willful promotion of hatred was considered a justified limitation but the spreading of false news was not speaks volumes about the capacity of hate speech laws to deal with Holocaust denial. Though the decision in $R v$ Zundel has faced criticism, it is argued the decision was correct. The most persuasive rejection of Holocaust denial is through its relationship with hate speech. To criminalise speech purely on the basis of its falsity is to impose a substantial restriction on the right to freedom of expression. The willful promotion of hatred is a more pressing mischief given the harm it causes, and thus its restriction by the criminal law is more appropriate.

\section{New Zealand}

The right to freedom of expression is protected by s 14 of the New Zealand Bill of Rights Act 1990 (NZBORA). The right is not absolute, and is subject to limitations that can be demonstrably justified in a free and democratic society. ${ }^{99}$ Few limits on the right exist in New Zealand, ${ }^{100}$ however, any limitations imposed have been accepted with little debate. ${ }^{101}$

Consistent with other common law jurisdictions, New Zealand has no law explicitly criminalising Holocaust denial. The Human Rights Act 1993 makes hate speech on the basis of race unlawful. ${ }^{102}$ Section 61 of the Act (the civil provision) makes unlawful the publication, distribution or public expression of matter likely to excite hostility against or

\footnotetext{
${ }^{97}$ Robert Martin "Group Defamation in Canada" in Monroe H Freedman and Eric M Freedman (eds) Group Defamation and Freedom of Speech: The Relationship Between Language and Violence (Greenwood Press, Connecticut, 1995) 191 at 197.

${ }^{98}$ LW Sumner The Hateful and the Obscene: Studies in the Limits of Free Expression (University of Toronto Press, Toronto, 2004) at 172.

${ }^{99}$ New Zealand Bill of Rights Act 1990, s 5.

${ }^{100}$ Butler and Butler, above n 34, at 323.

${ }^{101}$ See Grant Huscroft "Defamation, Racial Disharmony and Freedom of Expression" in Grant Huscroft and Paul Rishworth (eds) Rights and Freedoms: The New Zealand Bill of Rights Act 1990 and the Human Rights Act 1993 (Brookers, Wellington, 1995) 171 at 171.

${ }^{102}$ Sections 61 and 131.
} 
bring into contempt a group of persons on the grounds of colour, race, or ethnic or national origin. ${ }^{103}$ Under s 61 , intent is irrelevant. Section 131 (similarly worded to s 61) is broader, and makes the incitement of racial disharmony a criminal offence. ${ }^{104}$ In contrast to s $61, \mathrm{~s}$ 131 requires intent to excite hostility or ill-will against, or bring into contempt or ridicule any group of persons on the basis of colour, race, or ethnic or national origins. ${ }^{105}$ Prosecution under this section requires the Attorney-General's consent. ${ }^{106}$

Prior to the introduction of the HRA, s 25 of the Race Relations Act 1971 governed the incitement of racial disharmony in New Zealand. Passed following the implementation of ICERD, the Act was an attempt to comply with New Zealand's international obligations under art 4 of the Convention. ${ }^{107}$ While complaints under the Act were common, prosecutions were infrequent. ${ }^{108}$ Like s 131 of the HRA, prosecutions under s 25 of the Race Relations Act required the consent of the Attorney-General. ${ }^{109}$ The only reported case under s 25 is King-Ansell v Police. ${ }^{110}$ The defendant was the leader of the National Socialist Party of New Zealand, and distributed 9000 pamphlets containing "inflammatory antiSemitic propaganda". ${ }^{111}$ The defendant appealed his conviction, ${ }^{112}$ and the Supreme Court granted leave to appeal to the Court of Appeal. The appeal was based on whether Jews were an "ethnic group" for the purposes of subs (1). The Court found that Jews were a particular ethnic group under s 25(1), the defendant's appeal was dismissed, and his conviction upheld. ${ }^{113}$

\footnotetext{
${ }^{103}$ Subsection 1.

${ }^{104}$ Punishable by a fine of up to $\$ 7000$ or a term of imprisonment up to 3 months.

${ }^{105}$ Emphasis added.

${ }^{106}$ Human Rights Act 1993, s 132.

${ }^{107}$ Thomson Reuters Human Rights Act 1993 (online looseleaf ed, Brookers) at [HR131.01]; Huscroft, above n 101 , at 203.

${ }^{108}$ Moses, above n 43, at 187.

${ }^{109}$ Race Relations Act 1971, s 26.

${ }^{110}$ [1979] 2 NZLR 531.

111 At 532.

${ }_{112}$ Police v King-Ansell (Auckland, M 1577/77, 27 June 1978).

${ }^{113}$ At 544.
} 
There have been no cases reported under ss 61 or 131 of the HRA. The one prosecution under s 131 did not lead to a conviction. ${ }^{114}$ The precise explanation for the under-utilisation of these sections is unclear. Legislation criminalising this sort of speech is symbolic of society's intolerance of racist attitudes, ${ }^{115}$ and arguably this was the intention of the legislature when enacting these two sections. The argument that hate speech is not as prevalent in New Zealand as in overseas jurisdictions is compelling, but cannot be determinative. This much can be demonstrated from the quantity of complaints of racial disharmony lodged at the Human Rights Commission. ${ }^{116}$ However, no further action under the Act was taken with regards to these complaints once the majority of them had been referred to mediation. ${ }^{117}$ This is because complaints that do not meet the threshold in the Act fall outside the jurisdiction of the Commission. ${ }^{118}$

The lack of action taken by the Commission is consistent with the idea that "hate speech" captures the very upper level of racist speech. In the 2012 Report to the Committee on the Elimination of Racial Discrimination, it was noted that the majority of complaints lodged containing offensive content would be unlikely to excite hostility against ethnic groups. ${ }^{119}$ This could indicate that perhaps the threshold requirements in ss 61 and 131 are too high. However, the Human Rights Commission has signaled that this high threshold is necessary,

\footnotetext{
114 In 2008, see Committee on Elimination of Racial Discrimination "International Convention on the Elimination of All Forms of Racial Discrimination: Reports Submitted by States Parties Under Article 9 of the Convention" (2012) CERD/C/NZL/20 at [90].

115 Paul Rishworth The Right to Freedom of Expression (2003) as cited in Human Rights Commission "The Right to Freedom of Opinion and Expression" (26 October 2010) <www.hrc.co.nz>; Huscroft, above n 101, at 210; Human Rights Commission "Section 2 - Civil and Political Rights" (15 December 2010) <www.hrc.co.nz> at 132 and 134; Moses, above n 43, at 195.

${ }^{116}$ Once figures have been adjusted to account for the number of complaints on single issues, the number of complaints have been consistent: 31 in 2007, 23 in 2008, 30 in 2009, and 21 in 2010, see the Committee on Elimination of Racial Discrimination, above n 114, at 15.

${ }^{117}$ Committee on Elimination of Racial Discrimination, above n 114, at 15.

${ }^{118}$ Human Rights Commission "Human Rights in New Zealand Today: New Zealand Action Plan for Human Rights - Central and Local Government" (2004) <www.hrc.co.nz>.

${ }^{119}$ Human Rights Commission, above n 118.
} 
bearing in mind the right to freedom of expression. ${ }^{120}$ It has been argued that s 131 of the Act is therefore "framed to do no more than strictly necessary to implement art 4" of ICERD. ${ }^{121}$ Moreover, the requirement under s 131 that consent of the Attorney-General is required is an additional bar on the availability of the offence.

A useful example of the hesitancy to pursue complaints is the Kupka case at Waikato University. ${ }^{122}$ A complaint regarding Kupka's online denial activism was made to the Race Relations Conciliator in 2000. The Conciliator stated that Kupka's writings were "unlikely to incite racial hatred in New Zealand." 123 This is illustrative of the high threshold under the Act, and speaks volumes about the capabilities (or lack thereof) of anti-Semitic Holocaust denial in online far-right forums to incite racial hatred in New Zealand.

That ss 61 and 131 of the HRA impose a limitation upon the right to freedom of expression, protected under s 14 of NZBORA, is not in dispute. Rishworth argues that the justification for such limitations, in the context of hate speech laws, is the avoidance of harm: ${ }^{124}$

\begin{abstract}
It is possible to trace genocide and acts of violence against racial and ethnic groups back to the development of attitudes in the community. And if the development of attitudes is targeted as a 'harm' to be avoided because it makes people more susceptible to incitements to violence, or more tolerant of violence being perpetrated by the state on racial groups, then the harm avoidance rationale can be invoked to justify some speech restrictions.
\end{abstract}

\footnotetext{
${ }^{120}$ In the context of s 61: Easton v Human Rights Commission HC Wellington CIV-2009-485-726, 10 February 2010 at [25] as cited in Thomson Reuters, above n 107, at [HR61.03]; Human Rights Commission, above n 118.

121 Thomson Reuters, above n 107, at [HR131.01]; New Zealand Law Commission as cited in Huscroft, above n 101, at 208 .

122 See Part II.

123 Winston Aldworth "University passed the buck: conciliator" The Waikato Times (online ed, 14 April 2000) at 3 as cited in Caldwell, above n 28, at 67.

${ }^{124}$ Human Rights Commission "Human Rights in New Zealand Today: New Zealand Action Plan for Human Rights - Hate Expression” (2004) <www.hrc.co.nz>.
} 
Whether statements of Holocaust denial would come within the hate speech provisions of the HRA is uncertain. New Zealand society is further removed from the immediate history of the Holocaust than European states. While it is certainly not being argued that an antiSemitic attitude is absent from New Zealand culture, ${ }^{125}$ arguably anti-Semitism is less prevalent given the comparatively lower Jewish population. ${ }^{126}$ Further, it can be argued that the threatened rise of neo-Nazi movements in New Zealand is not as great as in European jurisdictions. ${ }^{127}$ The historical influence of the New Zealand League of Rights, an extremist anti-Semitic political group, is minimal. ${ }^{128}$ However, New Zealand still prides itself on being a multicultural society. Therefore, it does not necessarily follow that Holocaust denial is less likely to be considered hate speech for the purposes of ss 61 and 131 of the HRA.

As established in King-Ansell $v$ Police on the predecessor legislation, Jews would be considered the necessary "ethnic ... group of persons" for the purposes of the Act. As a precursor to any analysis into the content of the expression, it must be established under both sections that the words or matter were broadcast, published or distributed in public, or used in any public place or within the hearing of persons in a public place. ${ }^{129}$

The analysis would hinge upon, first, whether the written publication or verbal expression was "threatening, abusive, or insulting." This is required for both s 61 and s 131. Under both sections, whether the expression meets this threshold is an objective standard, taken

${ }^{125}$ See generally Brendan Manning “Vile' desecration of Jewish headstones” The New Zealand Herald (online ed, 19 October 2012); New Zealand Herald "Racism mars New Zealand election campaign" The New Zealand Herald (online ed, 14 August 2014).

${ }^{126}$ In 2012, the Jewish population in New Zealand was approximately 7,500 (approximately 0.2 per cent of the total population), see Mandell L Berman Institute "World Jewish Population, 2012" (2013) North American Jewish Data Bank <www.jewishdatabank.org> at 62.

${ }^{127}$ See Huscroft, above n 101, at 199.

${ }^{128}$ Paul Spoonley The Politics of Nostalgia: Racism and the Extreme Right in New Zealand (Dunmore Press, Palmerston North, 1987) at 141 and 246.

${ }^{129}$ Section 131(1)(a) and (b); s 61(1)(a) and (b). Note that s 61(1)(c) also includes words which are threatening, abusive, or insulting if the person using the words knew or ought to have known that the words were reasonably likely to be published in a newspaper, magazine, or periodical or broadcast by means of radio or television. 
from the perspective of the reasonable person within the targeted group of persons. ${ }^{130}$ Even if not threatening or abusive, it is likely that Holocaust denial would be considered insulting, which prima facie appears to be a lower threshold, even if interpreted narrowly so as not to impinge too greatly on the freedom of expression. Statements that the Holocaust was a Jewish conspiracy are likely to be considered insulting to the reasonable Jewish person. Even "bare" Holocaust denial (for instance, that only 200,000 Jews were killed during the War) could be deemed insulting, given the anti-Semitic nature of even bare denial, insofar as such statements detract from the suffering of Jewish people during the War. Given that Holocaust denial operates on a sliding scale, it must be recognised that not all denial would automatically reach the threshold of threatening, abusive or insulting.

Secondly, the denial would need to either be likely to excite hostility or ill-will against Jews, or likely to bring the Jewish people into contempt. ${ }^{131}$ Under s 131 , this includes "ridicule", ${ }^{132}$ broadening the scope of expression that would come within the section. These inquiries are context dependent. ${ }^{133}$ Section 131 requires intent. The terms hostility and contempt are undefined, but it can be assumed that they would be interpreted consistently with freedom of expression guarantees. ${ }^{134}$ Case law prior to the current Act suggests that contempt means more than "just ragging, chaffing or robust badinage ... it connotes belittling and denigrating in circumstances where the humorous aspect takes second place." 135

This inquiry largely depends on the likelihood of the potential audience to be influenced by the speech. ${ }^{136}$ It is not enough that the communicator feels hostility or ill-will against

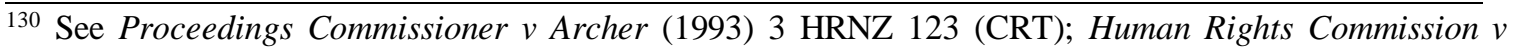
McCarthy (1983) 3 NZAR 450 (EOT); Skelton v Sunday Star Times 12/96 CRT 24/95 as cited in Thomson Reuters, above n 107, at [HR61.02] and [HR131.03].

${ }^{131}$ Note that s 131(1) would require intent.

${ }^{132}$ Section 131(1)(b).

133 Human Rights Commission "Balance about right, hate speech inquiry told" (5 May 2005) 〈www.hrc.co.nz>.

${ }^{134}$ Human Rights Commission, above n 124.

${ }^{135}$ Neal v Sunday News Auckland Publications Ltd (1985) 5 NZAR 234 as cited in Thomson Reuters, above n 107, at [HR61.05].

${ }^{136}$ Huscroft, above n 101, at 205.
} 
Jews; that sentiment has to be engendered in others. Blatantly anti-Semitic and aggressive Holocaust denial could perhaps excite hostility or ill-will against Jews, although this is uncertain, given New Zealand's intolerance for anti-Semitic attitudes. Holocaust denial could be seen to bring Jews into contempt or ridicule. Holocaust denial (both bare and aggravated) minimises the effects and harm of the Holocaust, which arguably creates feelings of contempt or worthlessness. Further, it is arguable that denial makes a mockery of the Holocaust and Jewish suffering, which could be found to constitute ridicule for the purposes of s 131.

However, whether reasonable persons would in fact be influenced by this speech, to the extent that hostility is incited, is unclear. Spoonley argues that despite the post-War resurgence of anti-Semitism in New Zealand, the far-right are still struggling to gain a captive audience for their anti-Semitic views. He argues the absence of a "popular base" of anti-Semitism in New Zealand is the reason for this. ${ }^{137}$ While Spoonley was writing over two decades ago, there is nothing to suggest that anti-Semitic discourse has now moved any more from the periphery to the centre of public consciousness. Until a case of Holocaust denial comes before the courts it is uncertain to what extent New Zealand hate speech legislation would encompass denial statements.

\section{The United States of America}

The United States has some of the strictest protections of free speech, taking a more "libertarian" approach. The First Amendment to the United States Constitution reads, "Congress shall make no law ... abridging the freedom of speech". In contrast to New Zealand and Canadian protections of free speech, United States protections are more absolute. While some exceptions to the First Amendment exist, the United States has no law prohibiting Holocaust denial, or even hate speech more generally.

Limitations to the First Amendment are narrow and specific. The first exception is the tort of libel. Secondly, the clear and present danger test was adopted to ensure that speech was

${ }^{137}$ Spoonley, above n 128 , at 36. 
limited only when it presented a "clear and present danger" to society. ${ }^{138}$ Adopted following World War I, this test has limited significance in the modern day. ${ }^{139}$

Third, a unanimous Supreme Court in Chaplinsky v New Hampshire established the fighting words doctrine. ${ }^{140}$ The Court held that "fighting" words are those that "by their very utterance inflict injury or tend to incite an immediate breach to the peace." ${ }^{141}$ Fighting words are restricted not because of their content, but because of their mode of expression. ${ }^{142}$ Subsequent courts have made efforts to narrow the scope of this doctrine, ${ }^{143}$ to those words likely to incite a violent response. ${ }^{144}$ Since Chaplinsky, the Supreme Court has not upheld a conviction based on this doctrine. ${ }^{145}$

Fourth, while content-based restrictions are generally not permitted, limitations may exist based on form, in the way of "time, place and manner" restrictions. ${ }^{146}$ Such restrictions must be content neutral, narrowly drafted, serve a legitimate government interest and not curtail other avenues of communication. ${ }^{147}$

Though hate speech is no less prevalent in the United States, no law exists prohibiting such speech. Racist speech will not be prohibited based on its content. Unless the speech reaches the threshold of one of the above exceptions, there is no legal restriction on its widespread expression. Similarly, there is no restriction on Holocaust denial in United States law. To be considered 'fighting words', the denial would have to be of a violent nature inciting an

\footnotetext{
${ }^{138}$ A real and immediate danger, see Shenck $v$ United States 249 US 47 (1919).

${ }^{139}$ See Lyrissa Barnett Lidsky and R George Wright Freedom of the Press: A Reference Guide to the United States Constitution (Praeger Publishers, Connecticut, 2004) at 20; Thomas Gardner and Terry Anderson Criminal Law (12th ed, Cengage Learning, Connecticut, 2012) at 229-230.

${ }^{140} 315$ US 568 (1942).

${ }^{141}$ At 572.

${ }^{142}$ RAV v City of St Paul 505 US 377 (1992) at 393.

${ }^{143}$ Street $v$ New York 394 US 576 (1969); Cohen v California 403 US 15(1971).

${ }^{144}$ Aronovitch, above n 78, at 155.

${ }^{145}$ Gardner and Anderson, above n 139, at 230.

${ }^{146}$ Grayned v The City of Rockford 408 US 104 (1972) at 116. See for example laws passed following Snyder v Phelps 562 US 9 (2011).

${ }^{147}$ Ward v Rock Against Racism 491 US 781 (1989) at 804.
} 
immediate breach of the peace. Parallels can be drawn between this doctrine and the requirement in s 130 of the German Criminal Code (public incitement) that the speech be "in a manner capable of disturbing the public peace".

Interestingly, much of Germany's Holocaust denial would reach this threshold required by the German Criminal Code. However, it is unlikely that Holocaust denial in the United States, without more, would constitute "fighting words" for the purposes of United States law. The ability of Holocaust denial to reach the threshold of disturbing the public peace in Germany and not reach that threshold in the United States is largely contextual. Because of Germany's immediate connection with the Holocaust and the desire to thwart the rise of neo-Nazism, the maintenance of "public peace" in Germany may be more committed to the complete eradication of anti-Semitism. Therefore, Holocaust denial in Germany is likely to be considered capable of disturbing the public peace. Even though the United States has one of the largest Jewish populations in the world, ${ }^{148}$ with less of an immediate connection to the Holocaust, it is unlikely that Holocaust denial would automatically incite an immediate breach of the peace. Moreover, the application of the fighting words doctrine has been significantly reduced in its application to racist hate speech, ${ }^{149}$ which Holocaust denial is most accurately framed as.

Given that the United States is one of the world's centres for Holocaust denial literature, the need for legal intervention to adequately deal with the potential harms of denial is pressing. Though there is growing criticism of the First Amendment's inability to deal with hate speech, the fervent protection of constitutional rights in the United States means that effective legal regulation of hate speech in the near future is unlikely.

\footnotetext{
${ }^{148}$ In 2012, the United States had a population of approximately 5.5 million Jews (approximately 1.7 per cent of the total population) behind Israel, with a population of approximately 5.9 million Jews (approximately 75 per cent of the total population), see Mandell L Berman Institute, above n 126, at 22.

${ }^{149}$ Cohen v California, above n 143 as cited in Michelle L Picheny "A Fertile Ground: The Expansion of Holocaust Denial into the Arab World" (2003) 23 BC Third World LJ 331 at 341.
} 


\section{The Necessity of Holocaust Denial Laws in Addition to Existing Hate Speech Laws}

Most jurisdictions that have laws explicitly prohibiting Holocaust denial also have more generalised hate speech laws, which begs the question: is there a need for explicit Holocaust denial laws, if Holocaust denial can come within existing hate speech legislation? Moreover, is having a separate offence for Holocaust denial implying that denial would not be covered by generic hate speech legislation? While hate speech laws were adopted incrementally across Europe, Holocaust denial laws were enacted in more of a "slippery slope" fashion. ${ }^{150}$ Specific Holocaust denial laws were required in the face of the proliferation of denial material as a result of increasing usage of the Internet. ${ }^{151}$ The uncertainty of whether denial would come within existing hate speech laws contributed to a desire to specifically criminalise Holocaust denial. ${ }^{152}$

Having distinct denial and hate speech laws, as in Germany, has not posed any problems in application. Section 130(1) of the Code, which deals with public incitement generally, appears to require a similar threshold to ss 130(3) and (4), the subsections pertaining specifically to Holocaust denial. Both subss (1) and (3) must be "in a manner that is capable of disturbing the public peace", and subs (4) requires the public peace be disturbed in actual fact, in a manner violating the dignity of the victims. The penalties under subss (1) and (3) are comparable. ${ }^{153}$ The penalty under subs (4) is slightly less punitive. ${ }^{154}$

While similar in many respects, the differences between the above provisions raise concerns over the "evenhandedness" of the enforcement of racist speech. ${ }^{155}$ If a lower threshold existed for hate speech against Jews than for speech against other ethnic

\footnotetext{
${ }^{150}$ Erik Bleich The Freedom to be Racist? How the United States and Europe Struggle to Preserve Freedom and Combat Racism (Oxford University Press, New York, 2011) at 59.

${ }^{151}$ See Bleich, above n 150, at 59; Credence Fogo-Schensul "More Than a River in Egypt: Holocaust Denial, the Internet, and International Freedom of Expression Norms" (1997-1998) 33 Gonz L Rev 241 at 242.

152 Bleich, above n 150, at 59.

${ }^{153}$ A period of imprisonment from three months to five years, and imprisonment not exceeding five years or a fine respectively.

154 Imprisonment not exceeding three years or a fine.

155 Bleich, above n 150, at 60.
} 
minorities, then perhaps such concerns would be justified. Under s 130, the "public peace" threshold is largely the same. Whether this requirement is satisfied would be highly context dependent, and may vary case-to-case. ${ }^{156}$

The unique historical context explains the existence of explicit Holocaust denial laws in Europe, and they are necessary for the symbolic role they play. An assessment of whether Holocaust denial is hate speech (for the purposes of various legislative regimes) cannot be divorced from the historical and cultural context. ${ }^{157}$ Even though Holocaust denial would likely come within hate speech legislation, the specific criminalisation of denial in Europe (and Israel) is symbolic. Banning denial is a legislative denunciation of neo-Nazism and anti-Semitism. Holocaust denial laws serve as a reiteration of the historically accepted facts of the Holocaust, and safeguard against their recurrence. Particularly in Germany, the laws are a necessary acknowledgement of responsibility for the Holocaust. Therefore, this Part concludes that explicit Holocaust denial laws are necessary for the specific purpose they serve in European states, however, generic hate speech laws are sufficient in non-European jurisdictions.

Following this Part's analysis on the laws prohibiting Holocaust denial and hate speech, it becomes necessary to examine the validity of such restrictions from a free speech perspective.

\section{Hate Speech, Holocaust Denial, and the Justifications for Free Speech Protection}

The three rationales underlying the freedom of expression are the marketplace of ideas, democracy and individual self-fulfilment. This Part introduces the three rationales and analyses them in the context of hate speech and Holocaust denial, and concludes that denial and hate speech are fundamentally inconsistent with all three rationales. It argues that when

\footnotetext{
${ }^{156}$ Bleich, above $\mathrm{n} 150$, at 60.

${ }^{157}$ See Parekh, above n 39, at 41 and 55; McGoldrick and O'Donnell, above n 3, at 485; Cohen-Almagor, above $\mathrm{n} 43$, at 35 and 39 .
} 
speech does not fulfil any of the rationales for free speech protection, it is justifiable to introduce restrictions.

The traditional, absolutist position on free speech has come under criticism. ${ }^{158}$ Particularly, the issues surrounding hate speech have instigated debate as to whether this type of speech fulfils any of the theories underlying freedom of expression. ${ }^{159}$ The denunciation of such speech has caused many jurisdictions to enact legislation criminalising hate speech. ${ }^{160}$ Historically, legislation prohibiting certain types of expression was passed with the aim of preventing war and preserving public peace. More recently, however, these laws suppress speech in an effort to protect the "rights of other individuals not to suffer an affront to their dignity." 161 This sea change is witnessed most clearly in the context of hate speech regulation.

There is conflicting discourse in hate speech jurisprudence. Egalitarian scholars posit that absent from hate speech are the necessary features that would demand rigid protection. ${ }^{162}$ Conversely, libertarian scholars argue that freedom of speech trumps individual dignity and equality. ${ }^{163}$

\section{A Truth and the Marketplace of Ideas}

The metaphor of the marketplace of ideas originated in John Milton's Areopagitica and John Stuart Mill's On Liberty, later to be solidified in Justice Holmes' dissent in Abrams v United States. ${ }^{164}$ According to Millian thought, society is more likely to uncover certain

\footnotetext{
${ }^{158}$ Wolfson, above $\mathrm{n} 37$, at 1.

${ }^{159}$ Wolfson, above n 37, at 1-2.

160 See Part III.

161 James Weinstein and Ivan Hare "General Introduction: Free Speech, Democracy, and the Suppression of Extreme Speech Past and Present" in Ivan Hare and James Weinstein (eds) Extreme Speech and Democracy (Oxford University Press, New York, 2009) 1 at 6-7.

162 Wolfson, above n 37, at 1-2.

163 Baez, above n 42, at 41; Catherine Lane West-Newman "Reading Hate Speech From the Bottom in Aotearoa: Subjectivity, Empathy, Cultural Difference” (2001) 9 Waikato L Rev 231 at 244.

164 John Milton Areopagitica: A Speech for the Liberty of Unlicensed Printing, to the Parliament of England (first published in 1644, reprinted by The Floating Press, Auckland, 2009); John Stuart Mill On Liberty (first
} 
truths if it promotes a free marketplace of ideas through uninhibited free speech. Furthermore, to prohibit an opinion would be to accept the infallibility of the state. Thus, Mill was of the opinion that society should endure even the speech it hates, because in an open debate where no opinion has been excluded, the truth will triumph. ${ }^{165}$ In Justice Holmes' famous dissent, he reiterated many of these ideas: ${ }^{166}$

... [T] he ultimate good desired is better reached by free trade in ideas - that the best test of truth is the power of the thought to get itself accepted in the competition of the market, and that truth is the only ground upon which their wishes safely can be carried out.

Based on this dicta, free speech absolutists argue the marketplace of ideas and the process of the pursuit of truth as justification for absolute protection. ${ }^{167}$ Free speech absolutists argue that the best remedy for bad speech is more speech. ${ }^{168}$ The metaphor suggests that ideas are like products. Good ideas will conquer in the market, and bad ideas will be defeated. ${ }^{169}$

An important distinction must be drawn between true and untrue statements, to determine the role of each in the market. Historically, governments used censorship to prohibit 'false' ideas that have now been accepted as fact. ${ }^{170}$ The United States Supreme Court has expressed disagreement over the function of false statements. In New York Times $v$ Sullivan, the Court asserted that a false statement can make a valuable contribution to

published in 1859, reprinted by Ticknor and Friends, Boston, 1863); Abrams v United States 250 US 616 (1919).

${ }^{165}$ As cited in Ronald Dworkin "Foreword" in Ivan Hare and James Weinstein (eds) Extreme Speech and Democracy (Oxford University Press, New York, 2009) i at vii.

${ }^{166}$ Abrams v United States, above n 164, at 630 (emphasis added).

${ }^{167}$ Allport, above n 43, at 25; Heyman, above n 34, at 64.

${ }^{168}$ See Leon Friedman "Freedom of Speech: Should It Be Available to Pornographers, Nazis and the Klan?" in Monroe H Freedman and Eric M Freedman (eds) Group Defamation and Freedom of Speech: The Relationship Between Language and Violence (Greenwood Press, Connecticut, 1995) 307 at 317.

169 Laura Beth Nielson Licence to Harass: Law, Hierarchy, and Offensive Public Speech (Princeton University Press, New Jersey, 2004) at 28; Jeremy Waldron The Harm in Hate Speech (Harvard University Press, Massachusetts, 2012) at 155; Gelber, above n 41, at 29.

${ }^{170}$ Fraleigh and Tuman, above n 34, at 10. 
public debate. ${ }^{171}$ Conversely, the Court in Hustler Magazine v Falwell held that "false statements of fact are particularly valueless; they interfere with the truth-seeking function of the marketplace of ideas." ${ }^{172}$ However, the dicta expressed in Hustler is caveated, insofar as the Court acknowledged the need to tolerate some false speech in order to prevent the "chilling effect" strict liability would have on the expression of true statements. ${ }^{173}$ The importance of not restricting this type of speech is reiterated by the idea that the marketplace is dynamic and "in constant flux" - perhaps some truths are subject to change. ${ }^{174}$

\section{Hate Speech and Holocaust Denial}

Holocaust denial is unique in that it can be framed in two ways: first, the expression of anti-Semitic hate speech, and second, the espousal of false speech to 'contest' historical facts. One argument to rebut the second analysis is that Holocaust denial should not be protected speech because deniers are merely asserting falsities, ${ }^{175}$ which provide no value to the marketplace of ideas. Thus, a characterisation of Holocaust denial purely as the espousal of false speech could potentially remove denial from a marketplace analysis. However, the marketplace theory is based on the assumption that decisions are informed and made only after "rational deliberation". ${ }^{176}$ This suggests that individuals are competent to distinguish truth from falsity. Government suppression of "false" speech raises issues. There is a risk in the government prescribing one universally applicable truth. Declaring certain historical facts about the Holocaust to be true may not be seen as contentious to many, given the almost unanimous acceptance of the statistics and figures. But, to do so would give the government a supreme power and would assume that truth is constant.

171376 US 254 (1964).

172485 US 46 (1988) at 52.

173 At 52.

${ }^{174}$ Wolfson, above n 37, at 146; Eric Barendt Freedom of Speech (Clarendon Press, Oxford, 1985) at 8.

${ }^{175}$ For example, assertions that only 200,000 Jews were killed during World War II.

${ }^{176}$ Baez, above n 42, at 50. 
A more persuasive rejection of the marketplace of ideas theory can be found in analysing Holocaust denial as a subset of hate speech. For Mill, the harm that speech may cause is not a sufficient justification for its suppression, ${ }^{177}$ and free speech absolutists argue that hate speech regulation injures the operation of the marketplace of ideas. ${ }^{178}$ However, the marketplace theory is fallible. It prioritises the search for truth (to the extent it is even possible) over competing values, such as the protection of human dignity. ${ }^{179}$ Perhaps the role of the state is to intervene to prevent harm to minorities; ${ }^{180}$ if so, this idea would extend to the protection of Jewish victims of anti-Semitic Holocaust denial.

Hate speech does not fulfil the marketplace theory. Free speech advocates assert the marketplace of ideas theory on the assumption that in the marketplace there exists an "even playing field", where individuals are equal participants. ${ }^{181}$ This is infrequently the case. Access to the marketplace is not "free" and equal. ${ }^{182}$ Uninhibited freedom of expression can operate to disadvantage minorities and the less privileged through unequal access to the marketplace. ${ }^{183}$ It is superficial to assert that the best remedy against evil speech is more speech. ${ }^{184}$ Victims of hate speech and Holocaust denial are not encouraged to "go to battle" with their aggressors in the marketplace. Thus, the marketplace ideology can operate to reinforce pre-existing inequalities if marginalised minorities are not given an equal opportunity to voice their opinions. ${ }^{185}$

\footnotetext{
177 Mill, above $\mathrm{n} 164$ as cited in Tourkochoriti, above $\mathrm{n}$ 36, at 589.

${ }^{178}$ See Baez, above n 42, at 46.

${ }^{179}$ Gelber, above n 41, at 30; Heyman, above n 34, at 170; Schauer, above n 44, at 132.

180 Tourkochoriti, above n 36, at 589; Karen Eltis "Hate Speech, Genocide, and Revisiting the "Marketplace of Ideas" in the Digital Age" (2011-2012) 43 Lov I Chi LJ 267 at 272.

${ }^{181}$ Cortese, above n 43, at 138.

${ }^{182}$ See Raphael Cohen-Almagor "Introduction" in Raphael Cohen-Almagor (ed) Liberal Democracy and the Limits of Tolerance: Essays in Honor and Memory of Yitzhak Rabin (University of Michigan Press, Ann Arbor, 2000) 1; Fraleigh and Tuman, above n 34, at 15; Butler and Butler, above n 34, at 308; Parekh, above n 39 , at 48 .

${ }^{183}$ See Fraleigh and Tuman, above n 34, at 14; Moon, above n 34, at 127; Cohen-Almagor, above n 43, at 36.

${ }^{184}$ Barendt, above n 174, at 13; Waldron, above n 169, at 157; Moon, above n 34, at 129.

${ }^{185}$ Cortese, above n 43, at 138 and 140; Kenneth Lasson "To Stimulate, Provoke or Incite?: Hate Speech and the First Amendment" in Monroe H Freedman and Eric M Freedman (eds) Group Defamation and Freedom of Speech: The Relationship Between Language and Violence (Greenwood Press, Connecticut, 1995) 267 at
} 
The presumption that all individuals come to the marketplace with rational deliberations is redundant when those individuals are victims of hate speech. Specifically, racism biases the marketplace. The marketplace theory is incapable of dealing with racist speech, because "racism is ubiquitous ... often we fail to see it because racism is so woven into our culture that it seems normal ... racist speech silences the politically weak". ${ }^{186}$ Hate speech goes far beyond causing mere insult. Racist hate speech silences minorities because of the disempowerment victims feel following a targeted attack. An attack based on a group the victim belongs to is a direct attack on a person's identity. Thus, the marketplace does not operate successfully for the victims of racist stereotyping. ${ }^{187}$ Rather than encouraging victims to add their voice to the marketplace, hate speech is a direct attack on victims' identity. ${ }^{188}$ As members of a minority group, this speech will not empower subjugated minorities to speak out against aggressive members of the majority.

Given the unique nature of Holocaust denial, the "silencing" argument is somewhat different when applied in this context. Because the Holocaust is nearly unanimously accepted as fact, and because society is highly suspicious of anti-Semitic discourse, speaking back against Holocaust denial is not speech contrary to the majority's narrative. However, denying facts of the Holocaust and assaulting the dignity of the Jewish community automatically puts Jewish victims on the defensive. Responding to Holocaust denial requires victims to validate the history of the Holocaust, something that, unsurprisingly, they might not believe is necessary. Moreover, responses to denial are largely at an academic rather than a social level. Thus, Holocaust denial still operates to silence its victims; it merely silences in a different way.

279; West-Newman, above n 163, at 253; Irwin Cotler "Racist Incitement: Giving Free Speech a Bad Name" in David Schneiderman (ed) Freedom of Expression and the Charter (Thomson Professional Publishing, Canada, 1991) 249 at 254.

${ }^{186}$ Charles Lawrence "If He Hollers Let Him Go: Regulating Racist Hate Speech on Campus" in Mari J Matsuda, Charles Lawrence, Richard Delgado and Kimberle Williams Crenshaw (eds) Words that Wound: Critical Race Theory, Assaultive Speech, and the First Amendment (Westview Press, Boulder, 1990) 53.

187 See Wolfson, above n 37, at 84.

188 See Wolfson, above n 37, at 84; Leets, above n 34, at 344. 


\section{B Democracy and the Democratic Process}

Freedom of expression is said to protect, promote and encourage citizen participation in the democratic process. In a democracy, the people have control over the government. ${ }^{189}$ Alexander Meiklejohn argued that freedom of expression is necessary for citizens to engage with political issues to successfully participate in a democratic society. ${ }^{190}$ Ronald Dworkin further argued that freedom of expression is "instrumental" to democracy and "constitutive" to its effective practice. ${ }^{191}$ The United States Supreme Court declared the democratic process as the ultimate purpose of free speech, as it assures "the unfettered interchange of ideas for the bringing about of political and social changes desired by the people." 192

Freedom of expression within public discourse is essential for the maintenance of democracy and political pluralism because it enables the communication of diverse ideas and fosters "collective self-determination". ${ }^{193}$ Thus, the democracy theory of free speech is primarily concerned with the ability of citizens to criticise the government and prevent abuses of power, ${ }^{194}$ and to have access to information about political leaders and the government to encourage educated and informed decision-making during the voting process. $^{195}$

\footnotetext{
${ }^{189}$ Gelber, above n 41, at 34; James Weinstein "Extreme Speech, Public Order and Democracy: Lessons from The Masses" in Ivan Hare and James Weinstein (eds) Extreme Speech and Democracy (Oxford University Press, New York, 2009) 23 at 25-26.

${ }^{190}$ Alexander Meiklejohn Free Speech and Its Relation to Self-Government (Port Washington, Kennikat Press, 1948).

${ }^{191}$ Dworkin, above $\mathrm{n} 165$, at viii.

${ }^{192}$ Roth $v$ United States 354 US 476 (1957) at 484.

${ }^{193}$ Tsesis, above n 43, at 497; Dieter Grimm "Freedom of Speech in a Globalized World" in Ivan Hare and James Weinstein (eds) Extreme Speech and Democracy (Oxford University Press, New York, 2009) 11 at 12; Jones, above n 45; Heyman, above n 34, at 170-171.

${ }^{194}$ Weinstein and Hare, above n 161, at 1; Fraleigh and Tuman, above n 34, at 8; Gelber, above n 41, at 34 .

${ }^{195}$ Sadurski, above n 42, at 20-21; Tourkochoriti, above n 36, at 592; Allport, above n 43, at 9; Barendt, above $\mathrm{n} 174$, at 20.
} 


\section{$1 \quad$ Hate Speech and Holocaust Denial}

Hate speech and Holocaust denial do not fulfil the democracy theory underlying free speech protection. The democracy theory is primarily concerned with the protection of political speech against the government, but carries less weight when concerned with hate speech by private individuals directed at other private individuals. ${ }^{196}$ Further, if democratic governance is the primary rationale, the theory is limited to the protection of political speech, ${ }^{197}$ and would not extend to hate speech. A distinction must be drawn between the democratic right of citizens to criticise the government, and hate speech, the target being vulnerable victims who often have no political power. ${ }^{198}$ However, it can be argued that Holocaust denial can be conceptualised as political speech, insofar as denier's may have an agenda to further far-right ideologies. ${ }^{199}$ Regardless, while perhaps carrying more weight with regards to government-related speech, it is generally accepted that freedom of expression extends beyond just political speech. Justification for this can be found on the basis that there is often an inherent overlap between politics and other social and public issues.

Dworkin argued that in a democratic society, citizens do not have the right to be free from insult or offence. ${ }^{200}$ However, racist speech provokes racial fears and hatred, and is thus antithetical to the social and political pluralism upon which democracy is based. ${ }^{201}$ If the speech is communicated in a society where racial prejudice exists, that society cannot be viewed as promoting democracy. ${ }^{202}$ Moreover, the democratic theory of

\footnotetext{
${ }^{196}$ Barendt, above n 174, at 22; Alan R Regel "Hate Propaganda: A Reason to Limit Freedom of Speech" (1984-1985) 49 Sask LR 303 at 308.

${ }^{197}$ Sadurski, above n 42, at 21-22; Regel, above n 196, at 308 and 317.

${ }^{198}$ Cortese, above $\mathrm{n} 43$, at 139.

199 Bazyler, above n 48, at 13; LW Sumner "Hate Propaganda and Charter Rights" in WJ Waluchow (ed) Free Expression: Essays in Law and Philosophy (Clarendon Press, Oxford, 1994) 153 at 153.

${ }^{200}$ Dworkin, above n 165, at viii.

${ }^{201}$ See Lasson, above n 185, at 269-270; Cotler, above n 185, at 254; Keith Dubick "Freedom to Hate: Do the Criminal Code Prescriptions Against Hate Propaganda Infringe the Charter?" (1990) 54 Sask LR 149 at 160; Cohen-Almagor, above n 43, at 36, Cortese, above n 43, at 137.

${ }^{202}$ See Wolfson, above n 37, at 86-87.
} 
"majoritarianism"203 may be unsuitable where racism permeates society. ${ }^{204}$ In such a society, Wolfson argues: 205

Democratic values are cheapened by this process, since the oppression by hateful speech lessens [the] ability [of subjugated groups] to participate on an equal basis in the democratic process. Hence, the role of free speech in advancing the processes of democracy ... is perverted by the words that wound.

Denial organisations ${ }^{206}$ could be perceived as antidemocratic. Hate speech and Holocaust denial do little to encourage equal participation in the democratic process. These and other online forums in which denial takes place do not encourage debate. Rather, hate speech and Holocaust denial cement existing inequalities and in turn undermine democracy. ${ }^{207}$ Therefore, while freedom of expression is a necessary component of democracy and collective decision making, hate speech undermines victims' collective decision-making capabilities, ${ }^{208}$ diminishing the ability of victims to effectively participate in the democratic process.

\section{Conflict with other Democratic Values}

The right to uninhibited freedom of expression, while essential to democracy, is in conflict with other fundamental democratic values. According to Barendt, democracy has a dual purpose: it could be interpreted to mean, first, majority rights, or secondly, the inalienable rights of all citizens that are incapable of being disregarded by the majority of the day (for example, the rights to human dignity and equality). ${ }^{209}$ Recognition and protection of these rights regardless of race or ethnicity is an essential component of democracy. ${ }^{210}$ This

\footnotetext{
203 The right of the majority to make decisions.

${ }^{204}$ Ronald Dworkin Taking Rights Seriously (Harvard University Press, Massachusetts, 1977) at 236 as cited in Gelber, above n 41, at 34.

205 Wolfson, above n 37, at 84.

${ }^{206}$ For example, the Institute for Historical Review.

207 See Tsesis, above n 43, at 505 and 512.

${ }^{208}$ See Tsesis, above n 43, at 532.

${ }^{209}$ Barendt, above n 174, at 21.

${ }^{210}$ Grimm, above n 193, at 12; Heyman, above n 34, at 170; Regel, above n 196, at 309.
} 
reiterates that democracy is more than a debate about politics; it extends to the governance of social relations. Particularly, citizens have a duty in a democratic society to respect the personhood of other individuals. ${ }^{211}$ Restrictions on speech are therefore justified when that speech is contrary to democracy. ${ }^{212}$

Holocaust denial has the ability to threaten democracy by undermining the individual dignity of its victims, and thus the "fabric of mutual respect" upon which democracy rests. $^{213}$ This is primarily due to the inherent anti-Semitic character of denial. Denial portrays Jews as greedy liars, orchestrating the "hoax" of the Holocaust for their own pecuniary and political benefit. ${ }^{214}$ Such racist slurs denigrate the Jewish people, constituting an attack on their dignity.

Competing human rights can come into conflict. Which democratic right should take precedence when rights do conflict is contested. Some scholars argue that the right to equality and personal dignity should trump the democratic "self-government of a nation". ${ }^{215}$ Conversely, pre-eminent scholar Robert Post posits that uninhibited freedom of speech is indispensable to democracy and thus should take priority. ${ }^{216}$ Post argues that restrictions on freedom of expression simply cannot stand in a democracy. ${ }^{217}$

\footnotetext{
${ }^{211}$ Heyman, above n 34, at 171.

212 See Cortese, above n 43, at 137; Cotler, above n 185, at 254.

213 Sevane Garibian "Taking Denial Seriously: Genocide Denial and the Freedom of Speech in the French Law" (2007-2008) 9 Cardozo J Conflict Resol 479 at 486; Waldron, above n 169, at 157; Parekh, above n 39 , at 44.

${ }^{214}$ For example, see App, above $n 7$.

215 Fraleigh and Tuman, above n 34, at 161; Grimm, above n 193, at 12.

216 Dworkin, above n 204 as cited in Waldron, above n 169, at 159; Robert Post "Racist Speech, Democracy, and the First Amendment” (1991) 32 Wm \& Mary L Rev 267 at 292.

217 As cited in Robert A Kahn "Why Do Europeans Ban Hate Speech? A Debate Between Karl Loewenstein and Robert Post” (2013) 41 Hostra L Rev 545 at 573.
} 
European legislative, judicial and academic opinion falls largely in favour of the protection of human dignity and equality. Drafted following the Second World War, ${ }^{218}$ the German Constitution protects human dignity as the principal value of the nation. ${ }^{219}$ Other European states place similar importance on the promotion of human dignity as a primary value. ${ }^{220}$ This could be a result of the continent's proximity to the War. However, even nations such as New Zealand and Canada have enacted hate speech legislation, ${ }^{221}$ arguably prioritising dignity over freedom of expression in limited circumstances. ${ }^{222}$

\section{Individual Self-Development and Self-Fulfilment}

The third theory underlying free speech protection is the notion that uninhibited freedom of expression contributes to individual self-development and self-fulfilment. Through exercising freedom of expression, individuals develop critical reasoning skills and a sense of "self". ${ }^{223}$ The argument is that any restrictions placed on information an individual is able to receive or impart will hinder his or her personal growth and development. ${ }^{224}$ Individuals will be prevented from reaching their full intellectual potential if their ability to formulate arguments and counter-arguments in the public sphere is circumscribed. ${ }^{225}$ Thus, freedom of expression and the process of engagement are essential for reaching selffulfilment. ${ }^{226}$

\footnotetext{
${ }^{218}$ The use of 'dignity' in European constitutional instruments increased exponentially following the Second World War, see generally Christopher McCrudden "Human Dignity and Judicial Interpretation of Human Rights" (2008) 19 EJIL 655 at 664 and 668.

${ }^{219}$ Basic Law for the Federal Republic of Germany, art 1.

${ }^{220}$ For example, Constitution of Poland 1997, art 30; Constitution of the Kingdom of Belgium, art 23; Czech Republic Charter of Fundamental Rights and Basic Freedoms, art 1.

${ }^{221}$ See Part III.

${ }^{222}$ New Zealand Human Rights Act 1993, ss 61 and 131; Canadian Criminal Code RSC 1985 c C-46, s $319(2)$.

${ }^{223}$ Parekh, above n 39, at 43.

${ }^{224}$ See Barendt, above n 174, at 14.

${ }^{225}$ See Barendt, above n 174, at 14.

${ }^{226}$ Sadurski, above n 42, at 17; Cohen-Almagor, above n 34, at 217; Grimm, above n 193, at 12; Tsesis, above n 43, at 497 and 499; Moses, above n 43, at 191.
} 
Post argues that in the United States, the First Amendment serves to protect the value of self-determination. ${ }^{227}$ According to Mill, informed and contested speech is vital to the process of individual self-development. Therefore, Mill would not necessarily oppose racist speech and its ability to contribute toward self-development. ${ }^{228}$

\section{$1 \quad$ Hate Speech and Holocaust Denial}

The argument from self-fulfilment can be criticised, and arguably has even less applicability in the context of hate speech and Holocaust denial. Dicta on personal development does not adequately address competing values. ${ }^{229}$ To assume that individual self-fulfilment is the primary purpose of free speech, often at the expense of individual dignity and self-worth, is misguided. It is superficial to assume that uninhibited free expression is the most effective way to achieve self-fulfilment and personal growth.

A limited argument from self-fulfilment can be made in defence of the denier's right to speak. Perhaps Holocaust denial can be defended on the ground that the deniers are maximising their individual self-fulfilment by formulating counter-arguments against conventional historical narrative. However, any self-fulfilment Holocaust deniers stand to gain from espousing hate speech is limited. Self-fulfilment is achieved by the exchange of well-informed ideas in a legitimate debate. It is not achieved by the one-sided delivery of distorted historical evidence. Additionally, Delgado stipulates, "[B]igotry, and thus the attendant expression of racism, stifles, rather than furthers, the moral and social growth of the individual who harbors it." 230 Thus, Holocaust deniers cannot rely in any meaningful way on the argument from self-fulfilment as a justification for the protection of their racist expression. Furthermore, this limited argument must be balanced against the negative effect Holocaust denial has on the self-fulfilment of its victims.

\footnotetext{
${ }^{227}$ Post, above n 216, at 281.

228 See Gelber, above n 41, at 31.

229 Tsesis, above n 43, at 499; Parekh, above n 39, at 43.

230 Richard Delgado "Words that Wound: A Tort Action for Racial Insults, Epithets, and Name-Calling" (1982) 17 Harv CR CLL R 133 at 176.
} 
Rishworth argues that hate speech laws are justified given the harm hate speech causes its victims. Regarding the contribution hate speech offers to individual self-fulfilment, he argues: ${ }^{231}$

... [P]eople should be spared the psychological harm and alienation that might follow racist remarks. The harm is not so much in the attitudes engendered in others, as in the erosion of self-worth in the victims, their withdrawal from society and resultant inequality.

Holocaust denial rejects the history and suffering of the Jewish people. Any effect hate speech has on the development of victims' identity is predominantly negative. ${ }^{232}$ This cannot be seen as consistent with individual self-fulfilment if the victim of hate speech is reluctant to talk back. Therefore, the self-fulfilment rationale is not convincing in the context of hate speech and Holocaust denial.

\section{The R v Keegstra Analysis}

In addition to being the subject of philosophical scholarly debate, these theories carry weight in judicial decisions. The Canadian Supreme Court in $R v$ Keegstra $^{233}$ discussed these three rationales for the protection of free speech. The Court argued that $s$ 2(b) of the Charter (the freedom of expression) protects. ${ }^{234}$

[T] he value of fostering a vibrant and creative society through the marketplace of ideas; the value of the vigourous and open debate essential to democratic government and preservation of our rights and freedoms; and the value of a society which fosters the self-actualization and freedom of its members.

\footnotetext{
${ }^{231}$ Rishworth, above $\mathrm{n} 115$.

${ }^{232}$ Clay Calvert "Hate Speech and Its Harms: A Communication Theory Perspective" (1997) 47 J of Communication 4 at 11; Cotler, above n 185, at 255.

${ }^{233}$ Above n 5, see Part III.

${ }^{234}$ At 863 , per La Forest, Sopinka and McLachlin JJ dissenting.
} 
Relevantly, the Court acknowledged that hate speech, however, does not satisfy these values that would warrant constitutional protection, having only a "tenuous connection" with s 2(b) values. ${ }^{235}$ Particularly, hate propaganda is contrary to individual dignity, equality and multiculturalism - values that Canada is committed to. ${ }^{236}$ The discussion of the freedom of expression rationales highlights their influence in both free speech theory and case law.

The Court discussed at length the marketplace of ideas theory in the context of the defendant's Holocaust denial. The Court acknowledged the persuasiveness of the theory, particularly given the goals of the Canadian Charter of Rights and Freedoms. ${ }^{237}$ However, the Court ruled that this theory did not provide support for the protection of hate speech; speech that the Court found to be characteristically false. The Court argued: ${ }^{238}$

\footnotetext{
Indeed, expression can be used to the detriment of our search for truth; the state should not be the sole arbiter of truth, but neither should we overplay the view that rationality will overcome all falsehoods in the unregulated marketplace of ideas. There is very little chance that statements intended to promote hatred against an identifiable group are true, or that their vision of society will lead to a better world. To portray such statements as crucial to truth and the betterment of the political and social milieu is therefore misguided.
}

This dicta is highly critical of the marketplace theory, and suggests that Holocaust denial, as a type of hate speech, hinders society's search for truth. The Court was of the view that where hate speech is involved, it is unlikely that the truth with prevail in the short run. What can be taken from the $R v$ Keegstra analysis is the importance of balancing the theories underlying free speech with other, competing societal values and goals.

\footnotetext{
235 At 795 .

236 At 755 .

237 At 762 .

238 At 763.
} 


\section{E To What Extent Should Speech That Does Not Fulfil any of the Underlying Theories of Free Speech be Protected?}

An analysis proving hate speech and Holocaust denial inconsistent with the justifications for protecting freedom of expression, as this Part has done, calls into question the extent to which this type of speech should be protected. The right to freedom of expression is not absolute. This Part has argued that it is when speech does not fulfil any of the justifications for free speech protection, restrictions on expression are justified on theoretical grounds. Such theoretical justifications support the hate speech regulation that has been implemented in many jurisdictions and internationally. ${ }^{239}$

It is put forward that in such situations, it is necessary for a balancing exercise to be undertaken. The advantages in protecting free speech must be balanced against the "chilling effect" hate speech has on its victims, and the harm it causes. ${ }^{240}$ Such an approach is pivotal in a diverse society. ${ }^{241}$ This approach is consistent with the balancing exercise that has been adopted by courts when assessing the validity of limitations on fundamental rights. $^{242}$

\section{$V$ Reconciling Holocaust Denial with the Right to the Freedom of Expression}

That the right to freedom of expression is a fundamental right in liberal democratic societies is undisputed. ${ }^{243}$ However, most jurisdictions acknowledge that the right is not absolute. When in conflict with other rights, courts are required to determine which should prevail in the circumstances, a principally contextual inquiry. This Part analyses the approaches taken in Canada, New Zealand and Germany when reconciling competing rights, and

\footnotetext{
239 Tourkochoriti, above n 36, at 587.

240 See Fraleigh and Tuman, above n 34, at 163.

${ }^{241}$ See Tsesis, above n 43, at 499.

242 See Part V.

${ }^{243}$ Butler and Butler, above n 34, at 307; Regel, above n 196, at 303; Tsesis, above n 43, at 521.
} 
concludes that the existing restrictions are justified as a necessary prioritisation of dignity and equality over free speech in the circumstances.

\section{A Canada and New Zealand}

Limitation clauses in legislation direct that many fundamental rights and freedoms guaranteed to citizens are not absolute. The Canadian Charter of Rights and Freedoms ${ }^{244}$ and NZBORA ${ }^{245}$ both stipulate that protected rights are subject only to such reasonable limits prescribed by law as can be demonstrably justified in a free and democratic society. Inherent in limitation clauses is the requirement that courts undertake a balancing exercise when considering the validity of various provisions, and when determining which right should prevail when rights are competing.

$R v$ Oakes outlined the balancing exercise to be undertaken by Canadian courts in such a situation. ${ }^{246}$ This test was subsequently adopted by the New Zealand Supreme Court in $R$ $v$ Hansen to determine whether a limitation on a fundamental right is justified under $\mathrm{s} 5$ NZBORA. ${ }^{247}$ In summary: ${ }^{248}$

a. Is the limiting measure sufficiently important to justify curtailment of the right or freedom?

b. Is the measure:

i. Rationally connected to its purpose?

ii. Limiting the right no more than is necessary to achieve the purpose?

iii. Applied proportionately to the importance of the purpose?

The Canadian Supreme Court has assessed the constitutional validity of Canada's hate speech legislation, and by a narrow majority, found it to be a justifiable limitation on the right to freedom of expression.

\footnotetext{
${ }^{244}$ Section 1.

245 1990, s 5.

${ }^{246} R$ v Oakes [1986] 1 SCR 103.

${ }^{247} R v$ Hansen [2007] 3 NZLR 1.

248 At [104].
} 


\section{Canadian Supreme Court Application to Holocaust denial in R v Keegstra (per Dickson CJ for the majority)}

As discussed in Part III, the Canadian Supreme Court in $R v$ Zundel found that $\mathrm{s} 181$ of the Canadian Criminal Code (the spreading of false news) was an unjustified limitation on the right to freedom of expression. Conversely, the Court in $R v$ Keegstra held that the limitation imposed by s 319(2) (the willful promotion of hatred) was justified. The balancing exercise undertaken by the majority in $R v$ Keegstra will be analysed in this section.

The $R v$ Oakes balancing test was applied in $R v$ Keegstra to determine the constitutional validity of s 319(2) of the Code. To determine the scope of the right of freedom of expression (under s 2(b) of the Charter), Dickson CJ analysed the values underlying the protection of free speech. ${ }^{249}$ Dickson CJ affirmed the scope of s 2(b) as broad and liberal, and rejected a blanket content-based restriction on speech. ${ }^{250}$ Keegstra's expression was held to be protected by s 2 (b) of the Charter. ${ }^{251}$

The majority first discussed whether the state action had an "objective of pressing and substantial concern" in a free and democratic society. The majority found this to be easily satisfied, by focusing on the harms that hate propaganda can cause. The incidence of racist hate propaganda was seen to be increasing, causing both psychological harm to victims (such as humiliation, degradation and emotional damage), and social harms to society generally. ${ }^{252}$ Dickson CJ considered international instruments prohibiting hate speech, ${ }^{253}$ and Canada's commitment to multiculturalism and equality. According to s 27 of the Charter, rights must be interpreted consistently with the preservation and enhancement of Canada's multiculturalism. Section 15 of the Charter stipulates that all citizens are entitled to equal protection under the law, without discrimination based on, amongst other things,

\footnotetext{
${ }^{249}$ See Part IV.

${ }^{250}$ At 728.

${ }^{251}$ At 698.

252 At 746-747.

${ }^{253}$ For example, ICERD and ICCPR.
} 
race and ethnicity. Thus, any analysis of the Court must be informed by these considerations. Concluding on limb one, Dickson CJ held that the objective in enacting $\mathrm{s}$ 319(2) was of the "utmost importance". ${ }^{254}$

The Court undertook a "proportionality" analysis to determine whether the infringement constituted a justified limitation under s 1 of the Charter. Dickson CJ acknowledged that a s 1 analysis could not be "rigid or formalistic", ${ }^{255}$ instead favouring a "sensitive" and "flexible" approach. ${ }^{256}$ Under the Oakes test, the following three prongs must be satisfied before the limitation is considered justified: the measure must be rationally connected to the objective, it must impair as little as possible the right in question, and there must be proportionality between the effects of the measure limiting the Charter right and the objective.

The majority held that there was a rational connection between s 319(2) and Parliament's objective of promoting equality, multiculturalism and social harmony. ${ }^{257}$ Dickson CJ rebutted the minority's concerns that a criminal prohibition of hate speech does nothing but give the propagandists undeserved media attention to further espouse their views. Dickson CJ stated that the criminal prohibition is symbolic of society's intolerance of hateful expression, and thus would not foster an acceptance of its content. ${ }^{258}$ For these reasons, the first prong was satisfied.

Second, the measure must impair as little as possible on the right to freedom of expression, protected by s 2(b) of the Charter. The fact that $s$ 319(2) is a criminal provision made this prong of particular concern. Because the provision is limited to public conversations, it requires intent, and four defenses are available, the provision was not too broad nor too vague, and thus was held to impair the s 2 (b) right as little as possible. ${ }^{259}$

\footnotetext{
254 At 758.

255 At 737.

256 At 737.

257 At 767.

258 At 699.

259 At 700.
} 
Third, there must be proportionality between the effects of the measure limiting the Charter and the objective. Dickson CJ did not see the infringement of s 319(2) on s 2(b) of the Charter as a serious restriction. The type of speech the provision aims to target is narrow and specific, only "tenuously connected" with the theories of free speech. ${ }^{260}$ Thus, the impairment was held to be proportionate.

Therefore, the majority held that although s 319(2) was an infringement on the right to freedom of expression, that limitation was demonstrably justified under s 1 of the Charter.

\section{To what extent would Dickson CJ's analysis apply in New Zealand?}

The validity of New Zealand's hate speech legislation has not been judicially tested, and a s 5 NZBORA analysis will not be undertaken in this paper. However, given the constitutional parallels between Canada and New Zealand, ${ }^{261}$ Dickson CJ's decision in $R v$ Keegstra is a useful guide to determine how a New Zealand court might approach a s 5 analysis in the context of hate speech legislation.

Section 319(2) of the Canadian Criminal Code is a criminal provision, therefore the $R v$ Keegstra proportionality analysis is more relevant to s 131 than s 61 of the HRA. The Canadian Charter emphasises the importance of protecting equality and multiculturalism, stressed by Dickson CJ in his judgment. NZBORA has no equivalent, other that the protection of minorities to enjoy the culture of that minority, and a general freedom from discrimination. ${ }^{262}$ Both s 319 (2) of the Code and s 131 of the HRA are limited to public communication, and require intent. The HRA provides no defences to the incitement of racial disharmony, in contrast to the Code, which provides four defences to the public incitement of hatred. ${ }^{263}$ This reduces the likelihood of s131 of the HRA being proportionate

\footnotetext{
${ }^{260}$ At 700 .

${ }^{261}$ See Cheryl Saunders "Protecting Rights in Common Law Constitutional Systems: A Framework for a Comparative Study” (2002) 33 VUWLR 507.

${ }^{262}$ Sections 20 and 19 respectively.

${ }^{263}$ Section 319(3).
} 
under prong 2. However, because s 131 of the Act is more narrowly drafted than s 319(2) of the Code, and thus would catch less speech, the disproportionality is less marked.

Extensive reference was made to the Canadian Charter in the NZBORA White Paper, and the Charter was hugely influential in the NZBORA drafting process. ${ }^{264}$ The limitation clause in s 5 of NZBORA is identical to the limitation clause in s 1 of the Charter. Given the similarities between the two documents, the White Paper intended for New Zealand courts to "draw on the rich and developing" Canadian jurisprudence when interpreting the Act. ${ }^{265}$ It is, therefore, unsurprising that the New Zealand Supreme Court in $R v$ Hansen adopted the $R v$ Oakes balancing test when determining whether a limit upon a right is demonstrably justified.

Given the constitutional parallels between the two jurisdictions and the influence of Canadian jurisprudence, it is likely a New Zealand court would approach the balancing analysis in a similar way, and would consider the decision in $R v$ Keegstra highly persuasive. However, the differences between the two statutory frameworks limit the extent to which Dickson CJ's analysis would apply in a New Zealand context. It is also important to note that Dickson CJ was delivering the decision of a narrow majority, and thus the issues at stake remain contentious. In any event, given the unwillingness of the Human Rights Commission to prosecute complaints, it is unlikely that the courts will have to deal with the issue, and thus a consideration of the constitutionality of New Zealand's hate speech legislation is uncalled for at present.

\section{B Germany}

The Basic Law of the Federal Republic of Germany protects free speech. Article 5(1) stipulates that "every person shall have the right to express and disseminate his opinion in speech, writing and pictures ...”. Subsection 2 states that these rights shall find their limits in the provisions of general laws, in provisions for the protection of young persons, and in

\footnotetext{
264 Department of Justice A Bill of Rights for New Zealand: A White Paper (1985) at 65.

265 Department of Justice, above n 264, at 65 and 72.
} 
the right to personal honour. Thus, the right to freedom of expression under German law is not absolute.

The relationship between the right to freedom of expression and Holocaust denial came to a head in National Democratic Party of Germany v Federal Republic of Germany (the “Auschwitz lie" case), heard by the Federal Constitutional Court. ${ }^{266}$ It should be noted from the outset that while a case of Holocaust denial, it was not a case concerning Holocaust denial laws per se. The plaintiff was a district association of the National Democratic Party (NPD) that invited David Irving to a conference. The Association was informed by the Munich authorities that Irving was prohibited from communicating Holocaust denial or "revisionism" during his lecture. The NPD filed a constitutional complaint, arguing that the decision violated their right to the freedom of expression, protected by art 5(1) of the Basic Law. On appeal, the Constitutional Court ruled against the NPD, finding that the decision of the authority to restrict the content of Irving's speech did not violate art 5(1). ${ }^{267}$

The Court acknowledged that the right to freedom of expression is not an unconditional guarantee. The basis of the decision was largely focused on the distinction between fact and opinion. The object of art 5(1) is the protection of opinions. Statements of Holocaust denial were considered to be (inaccurate) statements of fact, rather than the expression of opinion. Statements of Holocaust denial, therefore, could not be seen as pursuing the search for truth. Consequently, the Court held: ${ }^{268}$

... [T] he protection of assertions of fact ends at the point where they cease to contribute anything to the formation of opinion that is presupposed in constitutional law. From this point of view, incorrect information is not an interest worthy of protection.

\footnotetext{
${ }^{266}$ National Democratic Party of Germany v Federal Republic of Germany (Auschwitz Lie) (13 April 1993) BVerfGE 90241 translated by The University of Texas at Austin School of Law "Institute for Transnational Law: Foreign Law Translations" (2007) <www.utexas.edu $>$.

${ }^{267}$ Above n 266.

${ }^{268}$ Above n 266.
} 
Similar to the approaches adopted by Canada and New Zealand, the Court recognised that a balancing exercise must be undertaken when rights are in conflict. This exercise is between the basic right which has been restricted and the interest served by the restriction. ${ }^{269}$ In this case, the competing right was the injury to honour of the Jewish people, and Holocaust denial was considered an insult inflicted upon this group. The Court acknowledged: 270

It is true that in this case there is a presumption in favour of free speech. But this does not apply for statements which are insults in the formal sense or abuse, nor when a hurtful statement is based on factual assertions which are proved to be untrue.

Thus, relevant to the balancing exercise was the judicial acknowledgment that Holocaust denial was factually false, and therefore entitled to receive a lesser protection under art 5(1). ${ }^{271}$ This declaration by the Court is significant, and can be contrasted with the reluctance of Canadian courts to take judicial notice of the Holocaust. ${ }^{272}$ By accepting the historical facts of the Holocaust, German courts are denouncing Holocaust denial by implying it has no merit in historical inquiry. A second relevant consideration was the individual honour and dignity of the Jewish people. In this particular case, the insult to honour inherent in Holocaust denial was found to trump the right to freedom of expression.

This decision is indicative of the weight German courts place on protecting citizens' dignity and honour. The right to personal honour and dignity is the preeminent value and "spirit" of the Constitution, and often takes priority when rights are in conflict. ${ }^{273}$ The decision also

\footnotetext{
${ }^{269}$ Above $\mathrm{n} 266$.

${ }^{270}$ Above n 266.

${ }^{271}$ Above n 266.

${ }^{272}$ See discussion of $R v$ Zundel, Part III.

${ }^{273}$ Steven W Becker “ "I Think, Therefore I Am Guilty”: Suppressing Speech and Hijacking History - The Case Against Criminalizing Hate Speech and Revisionism as Global Policy" in Guiliana Ziccardi Capaldo (ed) The Global Community: Yearbook of International Law and Jurisprudence (Oxford University Press, New York, 2009) vol 17 at 17; Donald P Kommers (ed) The Constitutional Jurisprudence of the Federal Republic of Germany (Duke University Press, London, 1989) at 305 and 443.
} 
highlights the perceived harm that Holocaust denial has the capacity to cause. For these reasons, the limitation imposed on the NPD was considered to be justified.

What this Part has highlighted is the position courts are faced with when reconciling the freedom of expression with conflicting rights. The Canadian Supreme Court in $R v$ Keegstra held that hate speech legislation was demonstrably justified. While this decision would be persuasive in a New Zealand court, it is unclear whether Dickson CJ's approach would be adopted. Although not explicitly reconciling Holocaust denial laws with the freedom of expression in the Auschwitz Lie case, the approach of the Federal Constitutional Court of Germany similarly reiterated the importance of recognising and balancing competing rights when determining whether a decision is justified.

Contrasts can be drawn, however, between the competing rights prioritised by the Canadian and German courts. The Canadian Court stressed the importance of equality and multiculturalism. The German Constitutional Court emphasised the primacy of human dignity and honour. These distinct approaches are coloured not only by the legislative and constitutional framework within which the two states function, but also the social and historical context the legislative regimes operate within. Germany's desire to prioritise dignity and honour is an acknowledgement of the nation's responsibility for sacrificing these values during the War, and serves to prevent those values from being compromised in the future. This reinforces the paper's thesis that legislative restrictions on hate speech and Holocaust denial are justified as a necessary prioritisation of dignity and equality over absolute free speech in the circumstances.

\section{Denial and Defamation: Irving v Penguin Books Ltd and Lipstadt}

In 1996, David Irving sued author Deborah Lipstadt, her publisher, Penguin Books, and four London based bookstores for defamation. ${ }^{274}$ Irving filed suit in an English court,

\footnotetext{
${ }^{274}$ Irving later dropped the suit against the bookstores. Michael J Bazyler "The Holocaust on Trial: David Irving v Penguin Books Ltd and Deborah Lipstadt" in Bruce Alfran and Robert A Garber (eds) Jews on Trial (Princeton Jewish Centre, New Jersey, 2005) 225 at 228.
} 
claiming that Lipstadt had defamed him in her book, Denying the Holocaust: The Growing Assault on Truth and Memory. ${ }^{275}$ Broadly, the case was presented to the public as a freedom of expression issue, largely focusing on the right of historians to publish their academic work. $^{276}$ What ensued was a three-year long period of discovery, ${ }^{277}$ and a three month trial, putting Irving's historical methodology directly on trial, and indirectly trying the validity of Holocaust denial in an English court. This Part seeks to analyse the claim and the judgment, to evaluate the broader significance of the trial for Holocaust denial.

\section{A David Irving and his Claim}

As discussed in Part II, David Irving is perhaps one of the most notorious Holocaust deniers. In Denying the Holocaust, Lipstadt's intention was to "demonstrate how deniers misstate, misquote, falsify statistics, and falsely attribute conclusions to reliable sources." 278 Lipstadt asserted that Irving was "one of the most dangerous spokespersons for Holocaust denial", and "bends [historical evidence] until it conforms with his ideological leanings and political agenda". ${ }^{279}$

Irving's claim was that Lipstadt had defamed him by falsely accusing him of being a Holocaust denier and Hitler apologist who distorted historical evidence, thus making a direct attack on his competence as a historian and his personal ideological motivations. ${ }^{280}$ Irving asserted that the book's content was an attempt to "silence" him and destroy his reputation as a historian, and therefore was defamatory (in the sense that ordinary readers would think less of him) under English law.

\footnotetext{
${ }^{275}$ Lipstadt, above n 12.

276 Jenny Edkins Trauma and the Memory of Politics (Cambridge University Press, Cambridge, 2003) at 166167.

277 Bazyler, above n 274, at 228.

${ }^{278}$ Lipstadt, above n 12, at 111.

279 At 181.

${ }^{280}$ Irving v Penguin Books Ltd and Lipstadt, above n 6, at [3.2].
} 


\section{B The Trial and Judgment}

Irving represented himself at trial, and it was agreed by both parties and Gray $\mathbf{J}$ that the trial would judge-alone. ${ }^{281}$ What was at issue, as Gray $\mathbf{J}$ carefully reiterated following the trial, was "Irving's methodology and historiography, not what happened back in the [1940s]. ${ }^{" 282}$ In this way, he was attempting to ensure that the judgment would not be a mechanism to legitimise or delegitimise Holocaust denial more generally. Gray J, who presided over the trial, held that Lipstadt's statements in Denying the Holocaust were defamatory. ${ }^{283}$ In establishing the defence of justification, the defendants had to prove, first, that no objective, fair-minded historian could have arrived at the conclusions that Irving came to (and therefore he had misrepresented the evidence), and secondly, that these misrepresentations were deliberate. ${ }^{284}$

To prove that Irving misrepresented the evidence, Lipstadt and Penguin Books used the testimony of five esteemed historians to discredit Irving's assertions. The historians found Irving's work to be seriously flawed, and based on lies. ${ }^{285}$ After outlining the essential elements of Holocaust denial, historian Richard Evans canvassed how Irving's work constituted denial. ${ }^{286}$ The report of Auschwitz historian Robert Jan van Pelt reiterated that "overwhelming" evidence demonstrated approximately one million Jews were killed at the camp. ${ }^{287}$ Irving massively understated the quantum of Jewish deaths, denied the existence of homicidal gas chambers at concentration camps, and denied Hitler's knowledge of the Final Solution, to the extent there was such a policy. This was accepted by Gray $\mathbf{J}$ as constituting Holocaust denial. ${ }^{288}$

\footnotetext{
${ }^{281}$ David Hirsh Law Against Genocide: Cosmopolitan Trials (The Glass House, London, 2003) at 131.

282 Clare Dyer "Judging History" The Guardian (online ed, 17 April 2000) 10 as cited in Edkins, above n 276 , at 167 .

283 At [4].

284 At [4].

285 Bazyler, above n 274, at 234.

${ }^{286}$ Irving v Penguin Books Ltd and Lipstadt, above n 6, from [8.3].

${ }^{287}$ Irving $v$ Penguin Books Ltd and Lipstadt, above n 6, at [13.72].

${ }^{288}$ At [13.95].
} 
Notably, Irving was forced to make significant concessions during the trial. In his publications, Irving had consistently claimed that there was no official Nazi policy of mass Jewish extermination. However, at trial he admitted his error by acknowledging the mass shootings sanctioned by Hitler and carried out by the Einsatzgruppen. ${ }^{289}$ Further, Irving ultimately accepted the existence of gas chambers at Auschwitz, admitting that the chambers were used for killing Jews "on some scale." 290 Therefore, prong one of the defence was satisfied.

To prove the second prong of the defence (that the misrepresentations were deliberate), the defendants argued that the cause of Irving's denials was his anti-Semitism, and put forward persuasive evidence to that effect. Defence counsel presented Irving's diary entries, transcripts of his speeches and reports from his website to prove that he was motivated by anti-Semitism. ${ }^{291}$ Proving Irving's racism was essential to proving he had deliberately misrepresented the historical evidence as a result of his ideological prejudices. ${ }^{292}$

The judge found for the defendants, Lipstadt and Penguin Books, in a 349-page judgment, holding that Irving was a racist and an anti-Semite. ${ }^{293}$ In his conclusion, Gray J stated: "the defendants are justified in their assertion that Irving has seriously misrepresented Hitler's views on the Jewish question", through his misinterpretation and mistranslation of historical documents. ${ }^{294}$ Significantly, Gray J held that the totality of the evidence established that large numbers of Jews were systematically gassed at Auschwitz. ${ }^{295}$ To conclude, Gray J held: ${ }^{296}$

\footnotetext{
289 At [6.13].

${ }^{290}$ At [7.112].

${ }^{291}$ At [9].

${ }^{292}$ At [13.4].

${ }^{293}$ At [13.104-13.105].

${ }^{294}$ At [13.31].

${ }^{295}$ At [13.78].

${ }^{296}$ At [13.161].
} 
... Irving displays all the characteristics of a Holocaust denier. He repeatedly makes assertions about the Holocaust which are offensive to Jews in their terms and unsupported by or contrary to the historical record.

Following the judgment, ${ }^{297}$ Irving hired counsel and instructed them to apply for appeal to the Civil Division of the Court of Appeal. On 20 July 2001, his application was denied.

\section{The Significance of the Trial for Holocaust Denial}

Despite the ruling against him, Irving publically declared that it would not dissuade him from future denials. ${ }^{298}$ Criticising the result as "indescribable ... and perverse", ${ }^{299}$ Irving also declared the outcome "predictable", ${ }^{300}$ which begs the question as to why he pursued the claim, and what his motivations were for doing so. Following the judgment, Lipstadt stated there was never any doubt that she and Penguin Books would be successful: ${ }^{301}$

... I see this not only as a personal victory, but also as a victory for all those who speak out about hate and prejudice. It was a struggle for truth and for memory, and a fight against those who sow the seeds of racism and anti-Semitism.

While a defamation trial and not a trial of Holocaust denial, Irving $v$ Lipstadt has broader significance for Holocaust denial. Implicit in the judgment is the suggestion that if Irving's work is methodologically flawed, so too is the work of other deniers. This strikes at the heart of the historical and legal validity of Holocaust denial. Although historical methodology and practice changes over time, ${ }^{302}$ this judicial denouncement of Irving's

\footnotetext{
${ }^{297}$ High Court of Justice (Queen's Bench division).

298 Anthony Julius "Case Overview: Irving v Lipstadt" in Michael Berenbaum and Fred Skolnik (eds) Encyclopedia Judaica (2nd ed, Macmillan Reference, Detroit, 2007) vol 730 at 30.

${ }^{299}$ S Busfield "Unrepentant Irving blasts 'perverse judgment" The Guardian (online ed, 11 April 2000) as cited in Therese O'Donnell “Judicialising History or Historicising Law: reflections on Irving v Penguin Books and Lipstadt" (2011) 62 NILQ 291 at 319.

${ }^{300}$ Julius, above $\mathrm{n} 298$, at 30 .

${ }^{301}$ Steve Busfield "Irving loses Holocaust libel case" The Guardian (online ed, 11 April 2000).

${ }^{302}$ O'Donnell, above n 299, at 304.
} 
methods of historical inquiry arguably had the effect of publically discrediting Holocaust denial.

Further, while referring only to Irving and not to Holocaust deniers generally, Gray J acknowledged the anti-Semitic character of denial. This is relevant insofar as it lends weight to the argument that Holocaust denial is a targeted, racist attack against Jews, consistent with traditional hate speech theory. This declaration speaks volumes about the significance of the trial beyond issues associated with defamation.

Perhaps defamation is another legal avenue to discredit denial, one that goes beyond hate speech laws and explicit Holocaust denial laws. However, what is ironic is that it was Irving, the denier, who was the plaintiff in the case. It cannot be said with any certainty that Holocaust denial in and of itself would be sufficient to fall within the tort of defamation.

\section{The Criticisms of Denial on Trial}

Holocaust denial laws and the legal issues surrounding denial have been criticised, challenging the efficacy of prosecuting denial. It is argued by some that when Holocaust deniers are involved in a trial (whether being prosecuted, or indirectly as in Irving $v$ Lipstadt), the trial is merely a platform from which deniers can communicate their ideas to the masses. Trials provide deniers with publicity, and in some instances make them "martyrs" for free speech. ${ }^{303}$ For these reasons, it could be argued that trials of Holocaust denial are counterproductive. The Canadian Zundel trials and the Irving trials will be briefly considered as examples.

\footnotetext{
303 See Huscroft, above n 101, at 193; Moses, above n 43, at 194; HW Arthurs "Hate Propaganda - An Argument Against Attempts to Stop it by Legislation” (1976) 18 Chitty's Law Journal as cited in Regel, above n 196, at 312 .
} 
The Zundel Canadian trials ${ }^{304}$ generated a great deal of media attention, ${ }^{305}$ largely due to Zundel's attempts to attract publicity. Prior to being charged under the Criminal Code for the spreading of false news, Zundel was relatively unheard of. Because of the lower court judge's refusal to take judicial notice of the Holocaust, the trial provided Zundel with an opportunity to canvas his writings at length, and advance his denial theories in a judicial setting. Adding fuel to the fire, Zundel on several occasions wore a bulletproof vest to court, declaring he needed protection from angry Jews. ${ }^{306}$ Attempting to come across as a martyr for the freedom of expression, Zundel also wore a helmet with the slogan "Freedom of Speech". As a result of the lengthy trial and Zundel's antics, Zundel and his Holocaust denial achieved a status of national notoriety. ${ }^{307}$ At a press conference following the trial, he declared: "[the trial] cost me $\$ 40,000$ in lost work, but I got one million dollars' worth of publicity for my cause. It was well worth it." ${ }^{\text {,308 }}$

David Irving has received a lot of publicity worldwide as a result of his Austrian Holocaust denial trial, as well as the English decision in Irving $v$ Lipstadt. However, it is argued that concerns of widespread publicity should not be overstated. The publicity surrounding Irving's trials in both Austria and England was overwhelmingly negative. ${ }^{309}$ While the issue of Holocaust denial may have achieved a presence in ordinary homes through these trials, it does not necessarily follow that the public felt any sympathy for Irving, or that they saw any merit in his denial claims.

Therefore, the concerns about denial on trial should not be overstated. While it is true that a court trial can serve as a mechanism for deniers to get more exposure and publicity for their opinions, only in their extremist circles would they gain sympathy as free speech martyrs. Trials of Holocaust denial are significant insofar as they represent society's

\footnotetext{
304 See Part III.

${ }^{305}$ Hasian, above n 86, at 49.

${ }^{306}$ Hasian, above n 86, at 48.

${ }^{307}$ Evelyn Kallen "Never Again: Target Group Responses to the Debate Concerning Anti-Hate Propaganda" (1991) 11 Windsor YB Access Just 46 at 54 as cited in Bishop, above n 65, at 53.

${ }^{308}$ Bazyler, above n 48, at 14.

${ }^{309}$ Bleich, above n 150, at 60 .
} 
intolerance towards deniers, and implicitly affirm traditional historical narrative, reinforcing the argument that Holocaust denial laws perform an essential symbolic function.

\section{Conclusion}

The New Zealand examples of Joel Hayward and Hans Joachim Kupka demonstrate the international nature of the problem of Holocaust denial. Not only does denial pose a threat to the legitimacy of historical methodology, Holocaust denial laws (and hate speech laws more generally) raise several legal issues, particularly the extent to which they infringe on the passionately protected right to freedom of expression. This paper has argued that free speech theory and the weight of competing rights serve to justify the limits on free speech that the restrictions impose.

Holocaust denial and hate speech fail to satisfy the three rationales for free speech protection, and thus it is argued that laws criminalising Holocaust denial and hate speech can be defended on theoretical grounds. Conceptualised as a type of hate speech, Holocaust denial has little to offer the marketplace of ideas. The argument that the best remedy against hate speech is more speech has little merit if victims of hate speech are disempowered and discouraged from "going to battle" against their aggressors. Democracy is multifaceted: hate speech and Holocaust denial are contrary to the fundamental democratic values of equality and individual dignity. Any argument deniers can make from self-fulfilment is a limited one, and must be balanced against the damage hate speech does to the selffulfilment of its victims.

Interestingly, some states (such as Germany) have legislation criminalising hate speech generally, and Holocaust denial more specifically. Theoretical concerns regarding the implication that Holocaust denial is therefore not a type of hate speech are unfounded. Practical concerns over the evenhandedness in enforcing these sections, it is argued, should not be overstated, given the similarities in threshold requirements and penalties. This paper has argued that while Holocaust denial would be considered public incitement generally 
under German law, the explicit criminalisation of Holocaust denial is necessary in Germany (and other European states) for the symbolic purpose it serves. In assessing the validity of Holocaust denial laws, the historical and social context must be at the forefront of considerations involved. Given the continent's proximity to the War, Holocaust denial laws have the function of reiterating traditional Holocaust narrative, and of denouncing anti-Semitism and the threatened rise of neo-Nazism. Thus, even if the deterrent effect of these laws is minimal, their primary function is being served simply by the laws being on the books.

Hate speech laws are sufficient in non-European jurisdictions to capture the upper levels of harmful speech. New Zealand's HRA makes unlawful the incitement of racial disharmony, indisputably restricting the right to freedom of expression. Until a case of Holocaust denial comes before the courts, however, it is unclear the extent to which this type of expression would fall within either section. This paper has argued that Holocaust denial would be "insulting" to the reasonable Jewish person. What is less certain, however, is the extent to which reasonable persons in New Zealand are capable of being influenced by Holocaust denial, a necessary inquiry into the requirement that the expression incite hostility, or bring into contempt or ridicule the Jewish people. Given the under-utilisation of the two sections, providing reasons by way of analogy is problematic. Decisions of such a nature would have to be made by the courts on a case-by-case basis.

The legal significance of Holocaust denial extends beyond the existence and application of hate speech and Holocaust denial laws. Irving $v$ Lipstadt highlights the role denial can play in the context of the tort of defamation. The judgment is useful in reiterating the antiSemitic motivations of Holocaust deniers, and implies that denial is flawed from a methodological standpoint. While trials of Holocaust denial have been extensively criticised from an efficacy perspective, these concerns should not be overstated, given that the publicity denial trials attract is largely negative.

That Holocaust denial is an international issue is clear. That laws criminalising such speech are inconsistent with the freedom of expression is also undisputed. While these laws are 
justified, and in certain contexts necessary, it is less clear how effective they are in actually reducing levels of Holocaust denial. Effective education of Holocaust history in tandem with legal intervention is required before the desired reduction in Holocaust denial activity can be expected. 


\section{Appendix 1: German Criminal Code}

\section{Section 130 Incitement to hatred}

(1) Whoever, in a manner that is capable of disturbing the public peace

1. Incites hatred against segments of the population or calls for violent or arbitrary measures against them; or

2. Assaults the human dignity of others by insulting, maliciously maligning or defaming segments of the population,

Shall be punished with imprisonment from three months to five years.

(2) $[\ldots]$

(3) Whoever publicly or in a meeting approves of, denies or downplays an act committed under the rule of National Socialism... in a manner capable of disturbing the public peace shall be liable to imprisonment not exceeding five years or a fine.

(4) Whoever publicly or in a meeting disturbs the public peace in a manner that violates the dignity of the victims by approving of, glorifying, or justifying National Socialist rule of arbitrary force shall be liable to imprisonment not exceeding three years or a fine. 


\section{Bibliography}

\section{A Cases}

$1 \quad$ New Zealand

King-Ansell v Police [1979] 2 NZLR 531.

Police v King-Ansell (Auckland, M 1577/77, 27 June 1978).

$R v$ Hansen [2007] 3 NZLR 1.

\section{Canada}

$R v$ Keegstra (1984) 19 CCC (3d) 254.

$R v$ Keegstra (1988) 60 Alta LR (2d) 1.

$R v$ Keegstra [1990] 3 SCR 697.

$R v$ Oakes [1986] 1 SCR 103.

$R v$ Zundel [1992] 2 SCR 731.

\section{France}

Faurisson $v$ France, Communication No 550/1993, UN Doc CCPR/C/58/D/550/1993(1996).

\section{Germany}

National Democratic Party of Germany v Federal Republic of Germany (Auschwitz Lie) (13 April 1993) BVerfGE 90241.

\section{United Kingdom}

Irving v Penguin Books Ltd and Lipstadt [2000] EWHC QB 115.

6 United States of America

Abrams v United States 250 US 616 (1919).

Chaplinsky v New Hampshire 315 US 568 (1942).

Cohen v California 403 US 15(1971).

Grayned v The City of Rockford 408 US 104 (1972).

Hustler Magazine v Falwell 485 US 46 (1988). 
New York Times v Sullivan 376 US 254 (1964).

RAV v City of St Paul 505 US 377 (1992).

Roth v United States 354 US 476 (1957).

Shenck $v$ United States 249 US 47 (1919).

Street $v$ New York 394 US 576 (1969).

Ward v Rock Against Racism 491 US 781 (1989).

7 European Court of Human Rights

Garaudy v France no 65831/01 24 June 2003 (ECHR).

\section{B Legislation}

$1 \quad$ New Zealand

Bill of Rights Act 1990.

Human Rights Act 1993.

Race Relations Act 1971.

\section{Australia}

Racial Discrimination Act 1975.

\section{Belgium}

Constitution of the Kingdom of Belgium.

\section{Canada}

Canadian Charter of Rights and Freedoms (Constitution Act 1982, Part I).

Canadian Criminal Code RSC 1985 c C-46.

\section{France}

Gayssot Act.

\section{Czech Republic}

Charter of Fundamental Rights and Basic Freedoms. 


\section{Germany}

Basic Law for the Federal Republic of Germany.

German Criminal Code.

\section{Liechtenstein}

Criminal Code of the Principality of Liechtenstein.

9 The Netherlands

Dutch Penal Code.

10 Poland

Constitution of Poland.

11 United States of America

United States Constitution.

\section{Treaties and International Instruments}

Additional Protocol to the Convention on Cybercrime.

Charter of the International Military Tribunal.

Charter of the United Nations.

European Convention on Human Rights.

International Covenant on Civil and Political Rights.

International Convention on the Elimination of All Forms of Racial Discrimination. Universal Declaration of Human Rights.

\section{Books and Chapters in Books}

Alan Allport Freedom of Speech (Chelsea House, Philadelphia, 2003).

Austin J App The Six Million Swindle (Boniface Press, Tacoma Park, 1973). 
Hilliard Aronovitch "The Harm of Hate Propaganda" in Manjunath Pendakur and Roma M Harris (eds) Citizenship and Participation in the Information Age (Garamond Press, Ontario, 2002).

Stephen E Atkins Holocaust Denial as an International Movement (Praeger Publishers, Connecticut, 2009).

Susanne Baer "Violence: Dilemmas of Democracy and Law" in David Kretzmer and Francine Kershman Hazan (eds) Freedom of Speech and Incitement Against Democracy (Kluwer Law International, The Hague, 2000).

Benjamin Baez Affirmative Action, Hate Speech and Tenure: Narratives About Race and Law in the Academy (Routledge, New York, 2013).

C Edwin Baker "Autonomy and Hate Speech"; Ronald Dworkin "Foreword"; Dieter Grimm "Freedom of Speech in a Globalized World"; Steven J Heyman "Hate Speech, Public Discourse, and the First Amendment"; James Weinstein "Extreme Speech, Public Order and Democracy: Lessons from The Masses"; James Weinstein and Ivan Hare "General Introduction: Free Speech, Democracy, and the Suppression of Extreme Speech Past and Present"; Michael Whine "Expanding Holocaust Denial and Legislation Against It" in Ivan Hare and James Weinstein (eds) Extreme Speech and Democracy (Oxford University Press, New York, 2009).

Eric Barendt Freedom of Speech (Clarendon Press, Oxford, 1985).

Lyrissa Barnett Lidsky and R George Wright Freedom of the Press: A Reference Guide to the United States Constitution (Praeger Publishers, Connecticut, 2004).

Michael J Bazyler "The Holocaust on Trial: David Irving v Penguin Books Ltd and Deborah Lipstadt" in Bruce Alfran and Robert A Garber (eds) Jews on Trial (Princeton Jewish Centre, New Jersey, 2005). 
Steven W Becker ““'I Think, Therefore I Am Guilty”: Suppressing Speech and Hijacking History - The Case Against Criminalizing Hate Speech and Revisionism as Global Policy" in Guiliana Ziccardi Capaldo (ed) The Global Community: Yearbook of International Law and Jurisprudence (Oxford University Press, New York, 2009) vol 1.

Russ Bellant Old Nazis, the New Right, and the Republican Party: Domestic Fascist Networks and their Effect on US Cold War Politics (3rd ed, South End Press, Boston, 1991).

Erik Bleich The Freedom to be Racist? How the United States and Europe Struggle to Preserve Freedom and Combat Racism (Oxford University Press, New York, 2011).

Andrew Butler and Petra Butler The New Zealand Bill of Rights Act: A Commentary (Lexis Nexis, Wellington, 2005).

Arthur Butz The Hoax of the Twentieth Century: The Case Against the Presumed Extermination of European Jewry (Theses \& Dissertation Press, Chicago, 1976).

Sarah Cohen Antisemitism (KG Saur Verlag GmbH, Munich, 2004).

Raphael Cohen-Almagor (ed) Liberal Democracy and the Limits of Tolerance: Essays in Honor and Memory of Yitzhak Rabin (University of Michigan Press, Ann Arbor, 2000).

Anthony Cortese Opposing Hate Speech (Praeger, Connecticut, 2006).

Irwin Cotler "Racist Incitement: Giving Free Speech a Bad Name" in David Schneiderman (ed) Freedom of Expression and the Charter (Thomson Professional Publishing, Canada, 1991). 
Richard Delgado and Jean Stefanic Must We Defend the Nazis? Hate Speech, Pornography and the New First Amendment (New York University Press, New York, 1999).

Lawrence Douglas "Policing the Past: Holocaust Denial and the Law" in Robert C Post (ed) Censorship and Silencing: Practices of Cultural Regulation (Getty Research Institute, Los Angeles, 1998).

Ronald Dworkin Taking Rights Seriously (Harvard University Press, Massachusetts, 1977).

Jenny Edkins Trauma and the Memory of Politics (Cambridge University Press, Cambridge, 2003).

Rainer Erb "Public Responses to Antisemitism and Right-Wing Extremism" in Hermann Kurthen, Werner Bergmann and Rainie Erb (eds) Antisemitism and Xenophobia in Germany after Unification (Oxford University Press, Oxford, 1997).

Richard Evans Lying About Hitler: History, Holocaust and the David Irving Trial (Basic Books, New York, 2002).

Stanley Fish There's No Such Thing As Free Speech: And It's a Good Thing, Too (Oxford University Press, New York, 1994).

Douglas M Fraleigh and Joseph S Tuman Freedom of Expression in the Marketplace of Ideas (SAGE, California, 2011).

Leon Friedman "Freedom of Speech: Should It Be Available to Pornographers, Nazis and the Klan?"; Robert Martin "Group Defamation in Canada" in Monroe H Freedman and Eric M Freedman (eds) Group Defamation and Freedom of Speech: The Relationship Between Language and Violence (Greenwood Press, Connecticut, 1995). 
Thomas Gardner and Terry Anderson Criminal Law (12th ed, Cengage Learning, Connecticut, 2012).

Katharine Gelber Speaking Back: The free speech versus hate speech debate (John Benjamins Publishing, Philadelphia, 2002).

Aleksandra Gliszczynska-Grabias "Penalising Holocaust Denial: A View from Europe" in Charles Asher Small (ed) Global Antisemitism: A Crisis of Modernity (Brill Press, Amsterdam, 2013).

Deidre Golash (ed) Freedom of Expression in a Diverse World (Springer, New York, 2010).

DD Guttenplan The Holocaust on Trial: History, Justice and the David Irving Libel Case (Granta, London, 2001).

Steven J Heyman Free Speech and Human Dignity (Yale University Press, New Haven, 2008).

David Hirsh Law Against Genocide: Cosmopolitan Trials (The Glass House, London, 2003).

Grant Huscroft "Defamation, Racial Disharmony and Freedom of Expression" in Grant Huscroft and Paul Rishworth (eds) Rights and Freedoms: The New Zealand Bill of Rights Act 1990 and the Human Rights Act 1993 (Brookers, Wellington, 1995).

David Irving Hitler's War (Hodder \& Stoughton, London, 1977).

David Irving The War Path (The Viking Press, New York, 1978). 
Patrick James, Donald E Abelson and Michael Lusztig (eds) The Myth of the Sacred: The Charter, the Courts, and the Politics of the Constitution of Canada (McGill-Queen's University Press, Montreal, 2002).

Anthony Julius "Case Overview: Irving v Lipstadt" in Michael Berenbaum and Fred Skolnik (eds) Encyclopedia Judaica (2nd ed, Macmillan Reference, Detroit, 2007) vol 7.

Robert A Kahn "Holocaust Denial and Hate Speech"; Kenneth Lasson "Defending Truth: Holocaust Denial in the Twenty-First Century" in Ludovic Hennebel and Thomas Hochmann (eds) Genocidal Denials and the Law (Oxford University Press, New York, 2011).

Robert A Kahn Holocaust Denial and the Law: A Comparative Study (Palgrave Macmillan, New York, 2004).

Peter Knight Conspiracy Theories in American History: An Encyclopedia (ABC-CLIO, California, 2003).

Donald P Kommers (ed) The Constitutional Jurisprudence of the Federal Republic of Germany (Duke University Press, London, 1989).

Kenneth Lasson "To Stimulate, Provoke, or Incite? Hate Speech and the First Amendment" in Monroe H Freeman and Eric M Freeman (eds) Group Defamation and Freedom of Speech: The Relationship Between Language and Violence (Greenwood, Westport, 1995).

Charles Lawrence "If He Hollers Let Him Go: Regulating Racist Hate Speech on Campus" in Mari J Matsuda, Charles Lawrence, Richard Delgado and Kimberle Williams Crenshaw (eds) Words that Wound: Critical Race Theory, Assaultive Speech, and the First Amendment (Westview Press, Boulder, 1990). 
Deborah E Lipstadt Denying the Holocaust: The Growing Assault on Truth and Memory (Penguin, New York, 1993).

Luke McNamara Human Rights Controversies: The Impact of Legal Form (RoutledgeCavendish, London, 2007).

Alexander Meiklejohn Free Speech and Its Relation to Self-Government (Port Washington, Kennikat Press, 1948).

John Stuart Mill On Liberty (first published in 1859, reprinted by Ticknor and Friends, Boston, 1863).

John Milton Areopagitica: A Speech for the Liberty of Unlicensed Printing, to the Parliament of England (first published in 1644, reprinted by The Floating Press, Auckland, 2009).

Richard Moon The Constitutional Protection of Freedom of Expression (University of Toronto Press, Toronto, 2000).

Laura Beth Nielson Licence to Harass: Law, Hierarchy, and Offensive Public Speech (Princeton University Press, New Jersey, 2004).

Bhikhu Parekh "Is There a Case for Banning Hate Speech"; Julie C Suk "Denying Experience: Holocaust Denial and the Free-Speech Theory of the State"; Frederick Schauer "Social Epistemology, Holocaust Denial and the Post-Millian Calculus" in Michael Herz and Peter Molnar (eds) The Content and Context of Hate Speech: Rethinking Regulation and Responses (Cambridge University Press, New York, 2012).

Paul Rassinier The Drama of the European Jews (Steppingstones Publications, Maryland, 1975). 
Wojciech Sadurski Freedom of Speech and Its Limits (Kluwer Academic Publishers, Massachusetts, 1999).

Michael Shermer and Alex Grobman Denying History: Who Says the Holocaust Never Happened and Why do they say it? (Updated and expanded edition, University of California Press, Los Angeles, 2000).

Gerry Simpson Law, War and Crime (Polity Press, Cambridge, 2007).

Paul Spoonley The Politics of Nostalgia: Racism and the Extreme Right in New Zealand (Dunmore Press, Palmerston North, 1987).

LW Sumner "Hate Propaganda and Charter Rights" in WJ Waluchow (ed) Free Expression: Essays in Law and Philosophy (Clarendon Press, Oxford, 1994).

LW Sumner The Hateful and the Obscene: Studies in the Limits of Free Expression (University of Toronto Press, Toronto, 2004).

Robert J Van Pelt The Case for Auschwitz: Evidence from the Irving Trial (Indiana University Press, Indiana, 2002).

Samuel Walker Hate Speech: The History of an American Controversy (University of Nebraska Press, Nebraska, 1994).

Nicholas Wolfson Hate Speech, Sex Speech, Free Speech (Praeger Publishers, Connecticut, 1997).

\section{E Journal Articles}

Dino Bottos "Keegstra and Andrews: A Commentary on Hate Propaganda and the Freedom of Expression" (1988-1989) 27 Atla L Rev 461. 
Clay Calvert "Hate Speech and Its Harms: A Communication Theory Perspective" (1997) $47 \mathrm{~J}$ of Communication 4.

Raphael Cohen-Almagor "Freedom of Expression v Social Responsibility: Holocaust Denial in Canada" (2013) 28 J of Mass Media Ethics 42.

Raphael Cohen-Almagor "Hate in the Classroom: Free Expression, Holocaust Denial and Liberal Education" (2008) 114 American J Education 215.

Raphael Cohen-Almagor "Holocaust Denial is a Form of Hate Speech" (2009) 2 Amsterdam L Forum 33.

Richard Delgado "Words that Wound: A Tort Action for Racial Insults, Epithets, and Name-Calling” (1982) 17 Harv CR CLL R 133.

Keith Dubick "Freedom to Hate: Do the Criminal Code Prescriptions Against Hate Propaganda Infringe the Charter?” (1990) 54 Sask LR 149.

Karen Eltis "Hate Speech, Genocide, and Revisiting the "Marketplace of Ideas" in the Digital Age" (2011-2012) 43 Lov I Chi LJ 267.

Credence Fogo-Schensul "More Than a River in Egypt: Holocaust Denial, the Internet, and International Freedom of Expression Norms" (1997-1998) 33 Gonz L Rev 241.

Sevane Garibian "Taking Denial Seriously: Genocide Denial and the Freedom of Speech in the French Law" (2007-2008) 9 Cardozo J Conflict Resol 479.

Marouf A Hasian Jr "Canadian Civil Liberties, Holocaust Denial, and the Zundel Trials" (1999) 21 Communications and the Law 43. 
Jeremy Jones “Holocaust Denial: 'Clear and Present' Racial Vilification” (1994) 10 AJHR 169.

Robert A Kahn "Why Do Europeans Ban Hate Speech? A Debate Between Karl Loewenstein and Robert Post” (2013) 41 Hostra L Rev 545.

Evelyn Kallen "Never Again: Target Group Responses to the Debate Concerning AntiHate Propaganda" (1991) 11 Windsor YB Access Just 46.

Roy Leeper "Keegstra and RAV: A Comparative Analysis of the Canadian and US Approaches to Hate Speech Legislation" (2000) 5 Communication Law and Policy 295.

Laura Leets "Experiencing Hate Speech: Perceptions and Responses to Anti-Semitism and Antigay Speech” (2002) 58 J of Social Science Issues 341.

Kathleen Mahoney “ $R$ v Keegstra: A Rationale for Regulating Pornography?” (1991-1992) 37 McGill LJ 242.

Mari Matsuda “Public Responses to Racist Speech: Considering the Victim's Story" (1989) 87 Mich L Rev 2320.

Christopher McCrudden "Human Dignity and Judicial Interpretation of Human Rights" (2008) 19 EJIL 655.

Dominic McGoldrick and Therese O’Donnell "Hate Speech Laws: Consistency with National and International Human Rights Law” (2006) 18 LS 453.

Juliet Moses "Hate Speech: Competing Rights to Freedom of Expression" (1996-1999) 8 Auckland U L Rev 185. 
Denise Mulvihill "Irving v Penguin: Historians on Trial and the Determination of Truth Under English Libel Law” (2000) 11 Fordham Intell Prop Media and Ent LJ 217.

Therese O’Donnell “Judicialising History or Historicising Law: Reflections on Irving $v$ Penguin Books and Lipstadt” (2011) 62 NILQ 291.

Michelle L Picheny “A Fertile Ground: The Expansion of Holocaust Denial into the Arab World" (2003) 23 BC Third World LJ 331.

Robert Post "Racist Speech, Democracy, and the First Amendment" (1991) 32Wm \& Mary L Rev 267.

Alan R Regel "Hate Propaganda: A Reason to Limit Freedom of Speech" (1984-1985) 49 Sask LR 303.

Cheryl Saunders "Protecting Rights in Common Law Constitutional Systems: A Framework for a Comparative Study" (2002) 33 VUWLR 507.

Gerald Tishler "Debate: Freedom of Speech and Holocaust Denial" (1986-1987) 8 Cardozo L Rev 559.

Ionna Tourkochoriti "Should Hate Speech Be Protected? Group Defamation, Party Bans, Holocaust Denial and the Divide between (France) Europe and the United States" (2014) 45 Colum Hum Rts L Rev 552.

Alexander Tsesis "Dignity and Speech: The Regulation of Hate Speech in a Democracy" (2009) 44 Wake For L Rev 497.

Jonathan D Varat "Deception and the First Amendment: A Central, Complex, and Somewhat Curious Relationship" (2006) 53 UCLA L Rev 1107. 
Lorraine Eisenstat Weinrib "Hate Promotion in a Free and Democratic Society: $R v$ Keegstra" (1990-1991) 36 McGill LJ 1416.

Michael Whine "Expanding Holocaust Denial and Legislation Against It" (2008) 20 Jewish Pol Studies Rev 1.

\section{F Reports}

Committee on Elimination of Racial Discrimination "International Convention on the Elimination of All Forms of Racial Discrimination: Reports Submitted by States Parties Under Article 9 of the Convention" (2012) CERD/C/NZL/20.

Department of Justice A Bill of Rights for New Zealand: A White Paper (1985).

European Commission "Report from the Commission to the European Parliament and the Council on the implementation of Council Framework Decision 2008/913/JHA on combating certain forms and expressions of racism and xenophobia by means of criminal law" (2014) 27.

Paul Rishworth The Right to Freedom of Expression (Human Rights Commission, 2003).

\section{G Theses and Dissertations}

Christopher Bishop "Denying the Undeniable: Holocaust Denial, the Criminal Law, and Free Speech” (LLB (Hons) Research Paper, Victoria University of Wellington, 2007).

Jessica Caldwell "Holocaust Consciousness in New Zealand 1980-2010: A Study" (Master of Arts thesis, Victoria University of Wellington, 2011). 
Monika Duppelfeld "Holocaust Denial Laws Versus Hate Speech Laws in General: How far can we Stretch the Freedom of Expression?” (LLM Research Paper, Victoria University of Wellington, 2009).

Joel Hayward "The Fate of Jews in German Hands: An Historical Enquiry Into the Development and Significance of Historical Revisionism" (Master of Arts thesis, University of Canterbury, 1993).

Sebastian Hoegl "Holocaust Denial: One's Free Expression of Thought or Just Hate Speech?” (LLM Research Paper, Victoria University of Wellington, 2008).

Holger Reinhardt "The Harm of Holocaust Denial v the Freedom of Expression: Hate Speech, and the Legal Response and the Search for a Universal Solution to a Universal Problem” (LLB (Hons) thesis, Victoria University of Wellington, 2011).

\section{H Internet Resources}

Anti-Defamation League "Extremism in America: Institute for Historical Review" <www.archive.adl.org>.

Anti-Defamation League "Holocaust Denial: An Online Guide to Exposing and Combating Anti-Semitic Propaganda" <www.archive.adl.org $>$.

Michael J Bazyler "Holocaust Denial Laws and Other Legislation Criminalizing Promotion of Nazism" (Podcast, 25 December 2006) Yad Vashem <www.yadvashem.com>.

Joel Hayward "Addendum: The Fate of Jews in German Hands: An Historical Enquiry into the Development and Significance of Holocaust Revisionism" (26 January 2000) University of Canterbury <www.canterbury.ac.nz>. 
Joel Hayward Working Party "Report by the Joel Hayward Working Party: Executive Summary" (20 December 2000) University of Canterbury <www.canterbury.ac.nz>.

Joel Hayward Working Party "Report to the Council of the University of Canterbury of the Working Party established to enquire into: the circumstances under which the degree of Master of Arts (with First Class Honours) was awarded by the University in 1993 to Joel Stuart Andrew Hayward, on the basis of a thesis entitled 'The Fate of Jews in German Hands: An Historical Enquiry into the Development and Significance of Historical Revisionism"' (20 December 2000) University of Canterbury <www.canterbury.ac.nz>.

Human Rights Commission "Balance about right, hate speech inquiry told" (5 May 2005) <www.hrc.co.nz>.

Human Rights Commission "Human Rights in New Zealand Today: New Zealand Action Plan for Human Rights - Central and Local Government” (2004)<www.hrc.co.nz>.

Human Rights Commission "Human Rights in New Zealand Today: New Zealand Action Plan for Human Rights - Hate Expression" (2004) <www.hrc.co.nz>.

Human Rights Commission "Section 2 - Civil and Political Rights" (15 December 2010) <www.hrc.co.nz>.

Human Rights Commission "The Right to Freedom of Opinion and Expression" (26 October 2010) <www.hrc.co.nz>.

Institute for Historical Review “About the IHR: Our Mission and Record" <www.ihr.org>.

Interview with Horst Mahler (Michel Friedman, Vanity Fair, 2007) transcript provided by Shoablogger Original Translations <www.shoablogger.wordpress.com>. 
Legislation Online "Dutch Penal Code 1881, amended 1994"; "Criminal Code of the Federal Republic of Germany English version" <www.legislationonline.com>.

Mandell L Berman Institute "World Jewish Population, 2012” (2013) North American Jewish Data Bank <www.jewishdatabank.org>.

Andrew E Mathis "Holocaust Denial, a Definition" The Holocaust History Project <www.holocaust-history.org>.

The Nizkor Project "Irving vrs. Lipstadt" <www.nizkor.org>.

Princeton University "Institute for Historical Review” <www.princeton.edu>.

United States Holocaust Memorial Museum "Holocaust Denial and Distortion" <www.ushmm.org>.

University of Canterbury "Hayward Thesis Working Party" <www.canterbury.ac.nz>.

The University of Texas at Austin School of Law "Institute for Transnational Law: Foreign Law Translations" (2007) <www.utexas.edu>.

\section{Newspaper Articles}

Steve Busfield "Irving loses Holocaust libel case" The Guardian (online ed, 11 April 2000).

S Busfield "Unrepentant Irving blasts 'perverse judgment"” The Guardian (online ed, 11 April 2000).

Clare Dyer “Judging History” The Guardian (online ed, 17 April 2000). 
"Holocaust denier in Germany sentenced to five years in prison - Europe - International Herald Tribune" The New York Times (online ed, 15 February 2007).

Brendan Manning "“Vile' desecration of Jewish headstones" The New Zealand Herald (online ed, 19 October 2012).

New Zealand Herald "Racism mars New Zealand election campaign" The New Zealand Herald (online ed, 14 August 2014).

Walter Reich "Erasing the Holocaust" New York Times Book Review (online ed, 11 July 1993).

Sean Scanlon "Making History” The Press (Christchurch, May 20 2000).

J Other

Council Framework Decision 2008/913/JHA on combating certain forms and expressions of racism and xenophobia by means of criminal law [2008] OJ L328/55. 